Rerearch paper

\title{
Prediction of potential for greenhouse gas mitigation and power recovery from a municipal solid waste landfill case in Tien Giang province, Vietnam
}

\author{
Long Ta Bui ${ }^{1,2^{*}}$, Phong Hoang Nguyen ${ }^{1,2}$ \\ ${ }^{1}$ Ho Chi Minh City University of Technology; longbt62@hcmut.edu.vn; \\ nhphongee407@gmail.com \\ ${ }^{2}$ Vietnam National University Ho Chi Minh City \\ *Corresponding author: longbt62@hcmut.edu.vn; Tel.: +84-918017376 \\ Received: 27 February 2021; Accepted: 15 April 2021; Published: 25 April 2021
}

\begin{abstract}
Research on landfill gases (LFGs) collection mainly consisting of $\mathrm{CH}_{4}$ and $\mathrm{CO}_{2}$ gases, is not only a solution to decrease environmental risks but also to utilize and generate an alternative clean power source of coal. Many typical landfill cases in Vietnam, which install a recovery system and remove captured $\mathrm{CH}_{4}$ by the flaring methods, are able to contribute to reducing significantly greenhouse gas $(\mathrm{GHG})$ emissions with roughly $0.25 \mathrm{tCO}_{2}-\mathrm{eq} /$ tons being equivalent to 7.8 million tons of $\mathrm{CO}_{2}-\mathrm{eq} / \mathrm{year}$. Furthermore, a wide range of LFG recovery projects financed by the World Bank was conducted on 27 landfills in 19 cities of Vietnam, which generated a potential of GHG emission reduction up to $1,116,068 \mathrm{tCO}_{2}$-eq/year. However, quantification of biogas emissions for each landfill as a basis in order to design and construct a suitable recovery system always has to face many challenges. The purpose of this study to propose an integrated system including a database combined with mathematical models in a Web-based packaged software named EnLandFill to be able to accurately quantify the emission load of GHGs and estimate electricity production generating from recovered LFGs. On a case study of Tien Giang province, total maximum cumulative emissions of LFGs, $\mathrm{CH}_{4}$, and $\mathrm{CO}_{2}$, which is around 279 million $\mathrm{m}^{3}$, 145 million $\mathrm{m}^{3}$, and 134 million $\mathrm{m}^{3}$ respectively, have been forecasted in scenario 1 for the period of 2021-2030. Additionally, the annual electricity generation potential is highest in scenario 2 , estimating a total value of over 800 million $\mathrm{kWh}$.
\end{abstract}

Keywords: Landfill; Munticipal Solid Waste; Methane; Models; Energy recovery potential.

\section{Introduction}

Recovery of $\mathrm{CH}_{4}$ gas from municipal solid waste (MSW) landfills with the aim of utilizing to generate biogas has been mentioned since the 70s of last century [1]. According to the Intergovernmental Panel on Climate Change (IPCC), the recovery of $\mathrm{CH}_{4}$ from landfills is the key to reduce GHGs from landfill [2]. The European Union (EU) countries already have regulations and strategies to encourage restrictions on landfill of biodegradable wastes, increasing the utilization of waste to decrease LFG emissions [3-5]. Many EU directives and IPCC guidelines have encouraged the use of energy from LFG $[2,6]$. From there, the task of evaluating the recovery efficiency of LFG $(\mathrm{E} \%)$ is necessary, to estimate the maximum recovery potential of $\mathrm{CH}_{4}$ gas collection system [7], as well as to use the recovered gas generating electricity and heat whilst contributing to GHG emissions reduction, bringing about economic benefits [8]. The United States and many European countries have led the remarkable achievements in creating energy from landfill biogas in the late $20^{\text {th }}$ century [9]. 
The problem of generating power source from MSW has attracted the attention of organizations and researchers around the world [9]. In the US, MSW landfill-the $2^{\text {nd }}$ largest source of artificial $\mathrm{CH}_{4}$ emissions with an estimated 30 million tons of $\mathrm{CO}_{2}-\mathrm{eq}$ in 2006 [10]. Since 1994, the Landfill $\mathrm{CH}_{4}$ Outreach Program (called LMOP) has been launched by the US EPA with the goal of reducing GHGs from landfills through the recovery and use of LFG as a renewable energy source [11]. As of December 2007, an estimated 450 LFG (or LFGE) power projects have been operated throughout the United States, producing approximately 1,380 MW of electricity per year and providing about 235 million $\mathrm{ft}^{3}$ of LFG/day to direct use [12].

In China, India, and some developed nations in ASEAN such as Thailand or Malaysia almost have focused on mining the common benefits from LFG recovery projects. Many facilities to accommodate LFG recovery have been built in the period of 2005-2010 [9]. In India, [13] determined the $\mathrm{CH}_{4}$ emission load from landfills in Delhi, respectively 1,288.99 $\mathrm{Gg} ; 311.18 \mathrm{Gg} ; 779.32 \mathrm{Gg}$ in the period 1984-2015 and corresponding energy generating potential reached $4.16 \times 10^{8}-9.86 \times 10^{8} \mathrm{MJ}$ for Ghazipur landfill; $2.08 \times 10^{8}-4.06 \times 10^{8} \mathrm{MJ}$ for landfill Okhla and $3.42 \times 10^{8}-8.11 \times 10^{8} \mathrm{MJ}$ for landfill Bhalswa [13]. The research team in Thailand evaluated the complex benefits of LFG energy recovery process for the Bang Kok area [14]. Life-cycle assessment (LCA) method has been applied to determine the GHG emission loads with a mitigation potential of $471,763 \mathrm{tCO}_{2}$-eq over a 10 -year LFG recovery period, equivalent to $12 \%$ of the total $\mathrm{CH}_{4}$ gas is generated.

According to the assessment of experts' Vietnam, if the recycling technologies are applied well, the gas recovery systems can contribute to reducing GHG emissions up to about $0.68 \mathrm{t}$ $\mathrm{CO}_{2} /$ ton of waste [15]. The World Bank-funded study forecasts 27 different landfills in the whole of Vietnam that implement LFG recovery projects [16]. In case of flaring GHGs, the potential reduction is about 1,116,068 $\mathrm{tCO}_{2}-\mathrm{eq} /$ year for the baseline landfill and 646,824 $\mathrm{tCO}_{2}-\mathrm{eq} /$ year for the new one. In the case of utilizing LFG to generate electricity, the total potential for mitigation is estimated at 2,006,969 $\mathrm{tCO}_{2}-$ eq/year. Particularly for My Tho City, Tien Giang with the total potential to minimize is forecasted at around 53,083 $\mathrm{tCO}_{2}-\mathrm{eq} /$ year [16]. In Hanoi, many given studies to recover and use LFG gas under the name of "Clean Development Mechanism (CDM)" [17] has been implemented in Nam Son landfill in Soc Son District and Tay Mo landfill in Tu Liem District. Baseline scenario results show that while LFG is recovered through collection and flaring system, it will significantly reduce environmental risks as well as contribute to GHG emissions reduction around 2,600,000 $\mathrm{tCO}_{2}-$ eq in the period $2010-2017$, an average of 373,696 $\mathrm{tCO}_{2}-$ eq/year [17].

As a good example at Go Cat landfill, Ho Chi Minh City has efficiently deployed an LFG recovery system with 21 vertically recovered wells [18]. Approximately 879,650 tons of LFG [18] have been collected, generating a total electricity capacity of about $2.43 \mathrm{MW}$ and annual electricity output of $16 \mathrm{GWh}$ [17]. Furthermore, two other CDM-based LFG collection projects have aslo been conducted in Phuoc Hiep and Dong Thanh landfills [15]. At Nam Binh Duong landfill since 2018, the power plant operating on recovered $\mathrm{CH}_{4}$ gas has been operated with a total power supply capacity of 9.1 million $\mathrm{kVA}$, by 2019 the total power supply has increased to 11.4 million kVA [19].

This study is carried out towards the determination of GHG recovery potential, towards the creation of renewable energy sources for local/national socio-economic goals. Selected objects for specific calculation are the Tan Lap 1 landfill in Tien Giang province, computing scenarios applying the EnLandFill Web-based software with consideration of LFG recovery and utilization of power generation are performed. The simulating results are also validated by monitoring data in order to evaluate the efficiency of the software. The specific study aims to find the most practical solution to allow local/national governments to recover energy, control, and reduce GHG emissions in the period of 2021-2030. Moreover, this research is also carried out within the framework of a Scientific research project at the National University of Ho Chi Minh City. 


\section{Methods and data}

\subsection{Study area}

Tien Giang is a province in the Mekong Delta region, one of eight provinces/cities in the Southern Key Economic Region; within the range of coordinates from $10^{\circ} 12^{\prime} 20^{\prime \prime}$ to $10^{\circ} 35^{\prime} 26^{\prime \prime}$ north latitude and from $105^{\circ} 49^{\prime} 07^{\prime \prime}$ to $106^{\circ} 48^{\prime} 06^{\prime \prime}$ east longitude. The whole province has a natural area of about $2,510.61 \mathrm{~km}^{2}$, accounting for $0.76 \%$ of the country's area and accounting for $6.2 \%$ of the entire Mekong Delta region [20]. Along with promoting socio-economic development, environmental issues, especially activities MSW management and treatment are being paid attention. The Department of Construction, together with the Department of Natural Resources and Environment, are the two focal points for MSW management in the province. Management has faced many challenges because most of them are open landfills, or landfill is unhygienic and always overloaded [20]. Currently, there are 8 active landfills in Tien Giang province, of which the Thanh Nhut landfill has only recently been operating, and 2 closed landfill sites including the Tan Thuan Binh landfill in Cho Gao District and the Binh Phu landfill in Cai Lay District [20].

Figure 1 presents a map of the study area, specifying the geographical location and the scope of the waste treatment area in Tan Lap 1 landfill. The total existing area of landfill is 14.88 ha in Tan Phuoc District, Tien Giang province, operating since 1999 [20]. The current landfill with an average treatment capacity of 340 tons/day, mainly treats waste by burial methods [20].

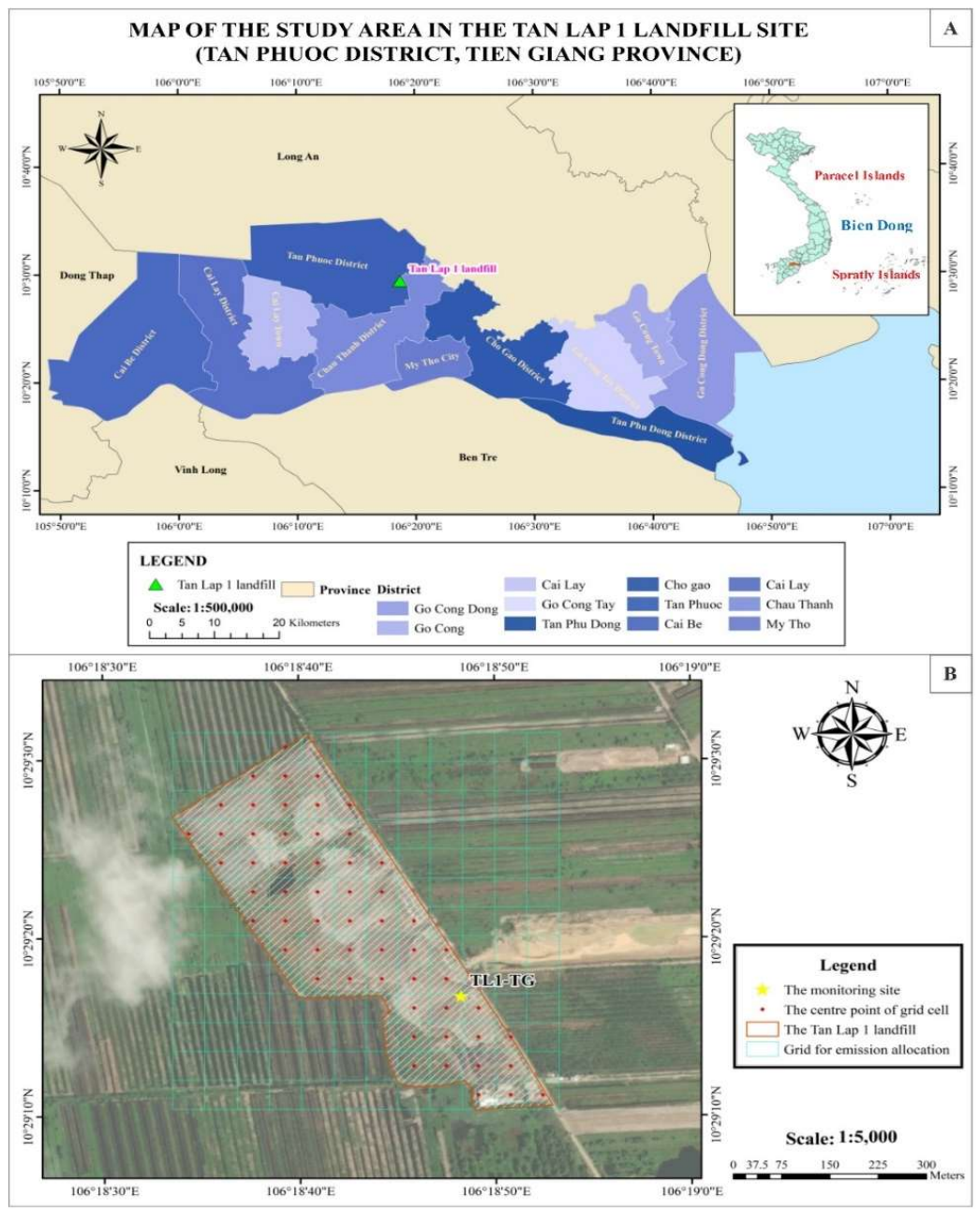

Figure 1. The study area at the Tan Lap 1 landfill in Tien Giang province, Vietnam (a) and (b). 


\subsection{Research framework}

The framework of this study is divided into six parts clearly. In particular, firstly, both the potential $\mathrm{CH}_{4}$ generation capacity parameter $\left(\mathrm{L}_{0}\right.$, opt(x), $\mathrm{m}^{3} /$ ton $)$ and the optimal $\mathrm{CH}_{4}$ generation rate coefficient $\left(\mathrm{k}_{\mathrm{opt}}\right.$, year $\left.{ }^{-1}\right)$ is determined as the input data of models. Secondly, the volume estimation of MSW (ton/year) is forecasted in the 2021-2030 period, which is based on prediction levels of the population as well as population growth rate in the study area and MSW generation potential rate. Thirdly, the annual LFG emission load $\left(\mathrm{m}^{3} /\right.$ year or ton/year) from the Tan Lap 1 landfill is also estimated in the same period using gathered data of buried MSW volume (ton/year) from 1999 to 2020 combined with the MSW volume predicting for the 2021-2030 period. Fourthly, a basis of LFG collection efficiency (E, \%), lower heating value of $\mathrm{CH}_{4}\left(\mathrm{MJ} / \mathrm{m}^{3}\right)$, landfill peak coating oxidation coefficient $(\mathrm{OX}, \%)$, power generation efficiency $(\delta, \%)$, and power factor $(\varepsilon, \%)$ are applied to assess the electricity production potential from the recovery of LFGs in the Tan Lap 1 landfill. Fifthly, the values of annual electricity production potential $(\mathrm{kWh} / \mathrm{year})$, the number of hours operating power stations throughout the year ( $\mathrm{D}_{\mathrm{hr}}$, hours), and the number of days operating power station in a year $(\gamma)$ is used to calculate expected capacity of the electricity generation stations (MW) from the captured LFGs. Finally, the effective assessment of recovered LFG usage as an alternative power source to traditional coal sources is performed through the amount of $\mathrm{CO}_{2}$ emission reduced in the future and the released GHGs emission mitigation according to different computing scenarios based on the Global Warming Potential (GWP) index.

The EnLandFill [21] software was selected to perform the first and third calculating steps. The approach applying in EnLandfill has been widely used in many parts of the world due to its simplicity and accuracy [22-24]. Additionally, this software has been automated processing in the form of packaged multi-modules applicable to specific conditions of Vietnam.

Building simulation scenarios, forecasting emission load of LFGs, consisting of total LFG (TLFG), $\mathrm{CH}_{4}$, and $\mathrm{CO}_{2}$ in the period of 2021-2030 based on Decision No. 1635/QĐUBND dated 24/05/2019 of People's Committee of Tien Giang province about Solid Waste Management Plan in Tien Giang province for the period 2011-2020, vision to 2030 [25]. Three detailed calculation scenarios are set up, including:

Scenario 1 (S1): All MSW generated from My Tho City, Cai Be Town and 04 districts in the study area including: Cai Lay, Chau Thanh, Tan Phuoc and Cho Gao are collected, partly transported, about $60 \%$ to 02 new treatment zones, the Eastern treatment area and the Western treatment area in Binh Xuan commune, Go Cong Town and Thanh Hoa commune, Tan Phuoc District, Tien Giang province. The remaining volume of solid waste, about $40 \%$, will be completely treated by burial method. In the period 2025-2030, a generation of generated gas collection system will be arranged, efficiency of $75 \%$, all collected gas will be served for electricity generation;

Scenario 2 (S2): All 100\% of MSW generated from My Tho City, Cai Be Town and 04 districts in the study area, Cai Lay, Chau Thanh, Tan Phuoc and Cho Gao is collected, transported and processed completely by burial method. In the period of 2021-2030, a generation gas collection system will be arranged with the collection efficiency of $75 \%$ for the period from 2021-2025 and 90\% for the period from 2026-2030; At the same time, all collected gas will be served for electricity generation;

Scenario 3 (S3): All 100\% of MSW generated from the whole study area is collected and transported to landfill treatment about $85 \%$ of the volume and $15 \%$ of the volume treated by combustion method. In the forecasting period of 2021-2030, a generation gas collection system will be arranged with the collection efficiency of $75 \%$ for the period from 2021 to 2025 and 90\% for the period from 2026-2030; At the same time, all collected gas will be served for energy generation. 


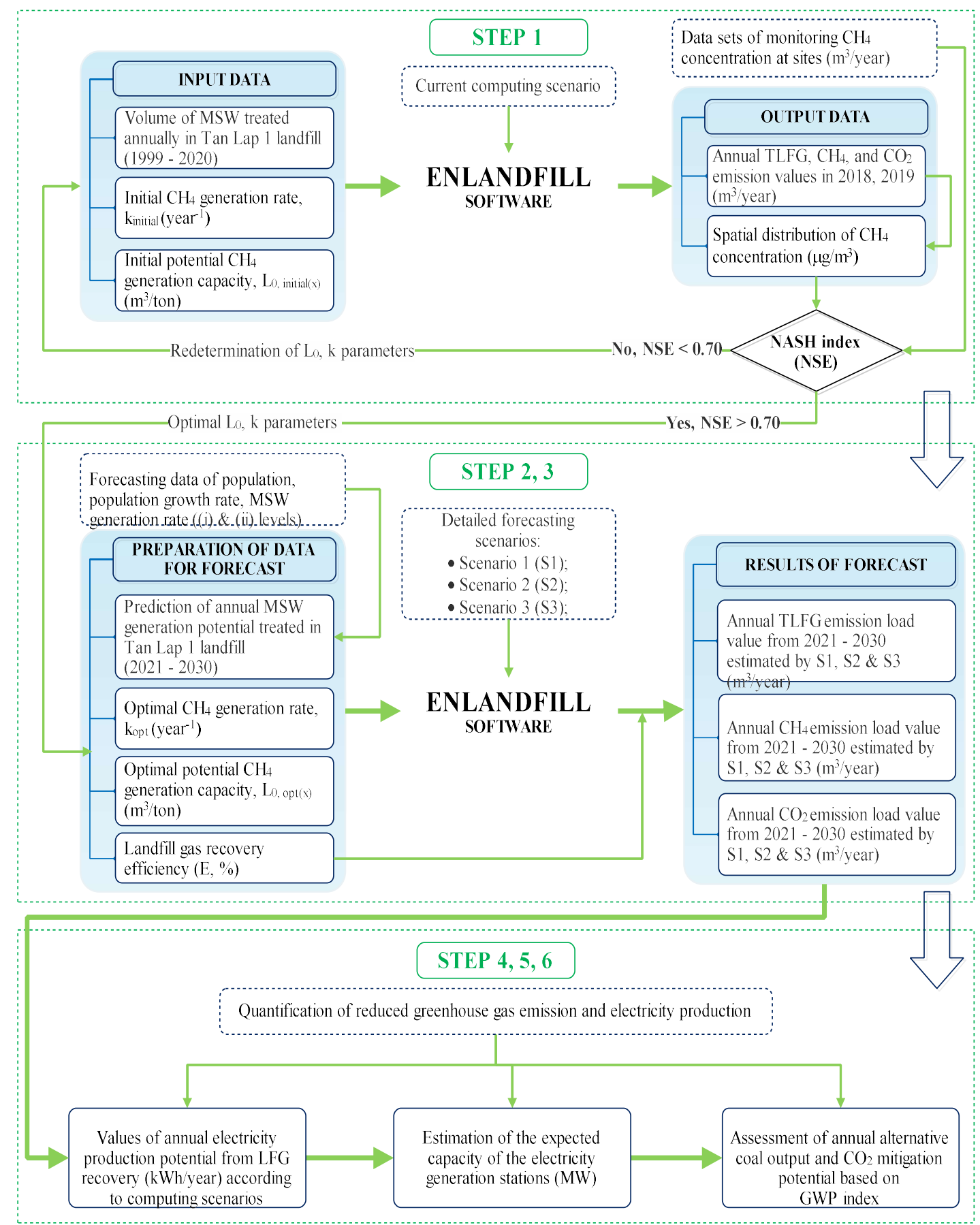

Figure 2. Conceptual framework of the applied methodology in this study.

\subsection{Models}

\subsubsection{EnLandFill software}

The results of experimental calculation through iteration calculations using EnLandFill software gave an estimated result of the potential coefficients of gas generation $\mathrm{CH}_{4}\left(L_{0}\right)$ and the optimal gas rate constant $(k)$ for research area. The Nash-Sutcliffe Statistical Index (NSE) is used to assess the optimal level of the set of coefficients $\left(L_{0}, k\right)$. Monitoring data of $\mathrm{CH}_{4}$ concentration was collected from reports of Tien Giang Department of Natural Resources and Environment, which was measuring times at 9.00 am on 25/03/2018, 8.00 am on 
$10 / 06 / 2018$, at 11.00 am on $10 / 09 / 2018$ and at 9.00 am on days $25 / 03 / 2019,10 / 06 / 2019$, $10 / 09 / 2019,11 / 11 / 2019$ at the TL1-TG monitoring position, Figure 1, are within the study area [26-27]. The EnLandFill software has been developed and tested based on meteorological data sets, mathematical models, and typical parameters with any landfill since the year 2019, which is applied to estimate LFG emission from MSW landfills of many Southern provinces [21].

\subsubsection{Estimation of electricity generation potential from the recovered landfill gas}

The electricity generation potential of MSW landfills depends on the total volume of $\mathrm{CH}_{4}$ recovered from LFG collection systems [23-24]. The FOD (First-Order Decay) model in the EnLandFill software can be used to determine LFG emissions for each year in this research area. It should be noted that only a fraction of the $\mathrm{CH}_{4}$ gas volume produced from organic matter degradable processes in landfills is able to be captured for electricity generation [24]. Therefore, the LFG recovery efficiency (E, \%) assumed in the period of 2021-2030 is around $75 \%$ to $90 \%$ [25]. The total generated $\mathrm{CH}_{4}$ gas volume from landfill captured to produce energy can be estimated as (1):

$$
\mathrm{CAP}_{\mathrm{CH}_{4 \text { Yeari }}}=\mathrm{E} \times(1-\mathrm{OX}) \times \sum_{\mathrm{i}=1}^{\mathrm{n}} \sum_{\mathrm{j}=0.1}^{1} \mathrm{k}_{\mathrm{opt}} \mathrm{L}_{0, \mathrm{opt}(\mathrm{x})}\left[\frac{\mathrm{M}_{\mathrm{i}}}{10}\right] \mathrm{e}^{-\mathrm{k}_{\text {opt }} \mathrm{t}_{\mathrm{j}}} \times \mathrm{D}_{\mathrm{CH}_{4}}
$$

The electricity generation potential, $\mathrm{EP}_{\mathrm{LFG}, \text { yeari }}$ (unit: $\mathrm{kWh} /$ year) from the total captured $\mathrm{CH}_{4}$ gas volume estimated for each operating year can be obtained as $(2)[9,13]$ :

$$
\mathrm{EP}_{\mathrm{LFG}, \text { yeari }}=\frac{\mathrm{CAP}_{\mathrm{CH}_{4 \text { Yeari }}} \times \mathrm{LHV}_{\mathrm{CH}_{4}} \times \delta \times \varepsilon}{\phi}
$$

where $\mathrm{LHV}_{\mathrm{CH}_{4}}$ is the Lower Heating Value (LHV) of $\mathrm{CH}_{4}$ gas (unit: $\mathrm{MJ} / \mathrm{m}^{3}$ ), and the $\mathrm{LHV}_{\mathrm{CH}_{4}}$ value is about from $35.0 \mathrm{MJ} / \mathrm{m}^{3}$ to $37.2 \mathrm{MJ} / \mathrm{m}^{3}[23,28,29] ; \delta$ is the capacity factor of the entire recovered $\mathrm{CH}_{4}$ combustion process to generate energy source, the common $\delta$ value is roughly $85 \%[23,30] ; \varepsilon$ is the electricity generation efficiency of the gas turbine engine, and is given a range of $30-35 \%[13,31]$; $\phi$ is the conversion factor from $\mathrm{MJ}$ to $\mathrm{kWh}$, and $\phi$ value is taken as 3.6 [23-24]. The energy plant size from captured $\mathrm{CH}_{4}$ gas of landfill ( $\mathrm{LFGTE}_{(\text {size) }}$ ) assuming it is able to operate throughout the year is calculated in $\mathrm{kW}$ or MW as (3) below [9, 23]:

$$
\operatorname{LFGTE}_{(\text {size })}=\frac{\mathrm{EP}_{\mathrm{LFG}, \text { yeari }}}{\mathrm{D}_{\mathrm{hr}} \times \gamma}
$$

where $D_{h r}$ is the number of hours in a day (unit: hours), and $\gamma$ is the number of days that power plant is worked in a year (unit: days).

\subsubsection{Calculating the amount of coal replaced and $\mathrm{CO}_{2}$ reduced from landfill gas}

Type of coal and oil thermal power generation accounts for the largest proportion of $38 \%$ with 20,056 MW of total power system capacity in Vietnam [32]. The proportion of imported coal for electricity production tends to rise from $3.9 \%$ in 2016 to $65.6 \%$ in 2030 [32], which is able to lead to financial risks, pressures on infrastructure costs and investment costs, along with energy security, environmental risks and public health [33].

Electricity production from the recovered LFG is a type of fuel instead of coal sources, thereby reducing the local dependence on imported coal as well as adding a clean energy souce. The mass flow rate of coal (unit: $\mathrm{kg} /$ hour) used as a fuel that is replaced by the captured $\mathrm{CH}_{4}$ gas through an LFG collection system can be calculated as (4) follows [34-35]: 


$$
\mathrm{m}_{\text {Coal }}=\frac{\mathrm{EP}_{\mathrm{LFG}, \text { yeari }}}{\mathrm{LHV}_{\mathrm{Coal}} \times \eta \times \tau}
$$

where $\mathrm{EP}_{\text {Coal, yeari }}$ is the electrical power generated from coal (unit: $\mathrm{MJ} /$ year); $\mathrm{EP}_{\mathrm{LFG} \text {,yeari }}$ is the electrical power produced from recovered LFG (unit: $\mathrm{MJ} / \mathrm{year}$ ); $\mathrm{m}_{\text {Coal }}$ is the mass flow rate of coal consumed or equivalent instead (unit: $\mathrm{kg} / \mathrm{hour}$ ); $\mathrm{LHV}_{\mathrm{Coal}}$ is the Lower Heating Value of coal (unit: $\mathrm{MJ} / \mathrm{kg}$ ); $\eta$ is the boiler efficiency (unit: \%), and $\tau$ is the operating time (unit: hour).

\subsubsection{Assessment of GHGs emission reduction potential from MSW landfills}

The MSW generation and treatment in landfills commonly including rapidly biodegradable waste that increased significantly GHG emissions releasing into the atmosphere [36], whilst LFG is mainly composed of $\mathrm{CH}_{4}$ and $\mathrm{CO}_{2}$ gases [37-39] contributing about 45$60 \%$ and $40-60 \%$ respectively [40]. Both $\mathrm{CH}_{4}$ and $\mathrm{CO}_{2}$ gases are the main GHGs because of their capacity to trap solar energy [41].

The Global Warming Potential (or "GWP") can be understood as a certain amount of GHG, released into the atmosphere causes a warming effect on the Earth [42] over a given period of time (normally 100 years) $[41,43]$. GWP is an index, with $\mathrm{CO}_{2}$ gas having the index value of 1 , and the GWP for all other GHGs is the number of times more warming they cause compared to $\mathrm{CO}_{2}$ [41]. The GWP values used to convert the GHG emissions from different unit to homogeneous unit called $\mathrm{CO}_{2}$ equivalent or $\mathrm{CO}_{2}$-eq shown in Table 1 [42]. The GHG emissions can be compared directly through a calculation based on (5) follows [41, 43]:

$$
\text { Emission }_{\mathrm{GHGi}_{\mathrm{CO}}-\mathrm{eq}}=\text { Emission }_{\mathrm{GHGi}} \times \mathrm{GWP}_{\text {index }, \mathrm{i}}
$$

where Emission ${\mathrm{GHGi}, \mathrm{CO}_{2}-\mathrm{eq}}$ is the emission of GHG i converted to the unit of $\mathrm{CO}_{2}$-eq; Emission $_{\mathrm{GHGi}}$ is the emission of GHG i estimated in the unit of ton or $\mathrm{kg}$, and $\mathrm{GWP}_{\text {index }, \mathrm{i}}$ is the Global Warming Potential of GHG i that can be referenced from Table 1 below.

Table 1. The GWP index values for $\mathrm{CO}_{2}$ and $\mathrm{CH}_{4}$ gases from the Report Assessment of IPCC.

\begin{tabular}{ccccc}
\hline \multirow{2}{*}{$\begin{array}{c}\text { Greenhouse Gas } \\
\text { (GHGs) }\end{array}$} & \multicolumn{4}{c}{ GWP values for 100-year time horizon } \\
\cline { 2 - 5 } & $\begin{array}{c}\text { Second } \\
\text { Assessment } \\
\text { Report (AR2) }\end{array}$ & $\begin{array}{c}\text { Third } \\
\text { Assessment } \\
\text { Report (AR3) }\end{array}$ & $\begin{array}{c}\text { Fourth } \\
\text { Assessment } \\
\text { Report (AR4) }\end{array}$ & $\begin{array}{c}\text { Fifth } \\
\text { Assessment } \\
\text { Report (AR5) }\end{array}$ \\
\hline Carbon Dioxide $\left(\mathrm{CO}_{2}\right)$ & 1 & 1 & 1 & 1 \\
Methane $\left(\mathrm{CH}_{4}\right)$ & 21 & 23 & 25 & 28 \\
\hline
\end{tabular}

To calculate the total value of GHG emission reduction potential generated from landfills for each year based on the computing scenario plan having biogas recovery to produce power generation can be shown in (6) $[36,44]$.

$$
\sum \mathrm{RE}_{\mathrm{GHGs} \text {,yeari }}=\mathrm{Q}_{\mathrm{CH}_{4} \text { Yeari }}^{\prime} \times \mathrm{GWP}_{\mathrm{CH}_{4}}+\mathrm{Q}_{\mathrm{CO}_{\mathrm{Y}_{\text {Yerri }}}} \times \mathrm{GWP}_{\mathrm{CO}_{2}}
$$

where $\sum \mathrm{RE}_{\mathrm{GHGs} \text {,yeari }}$ is the total GHGs emission reduction potential of the year $\mathrm{i}$ (unit: $\mathrm{tCO}_{2}$-eq/year); $\mathrm{Q}_{\mathrm{CH}_{4 \text { Yeari }}}$ and $\mathrm{Q}^{\prime} \mathrm{CO}_{2 \text { Yeari }}$ is the emissions of $\mathrm{CH}_{4}$ and $\mathrm{CO}_{2}$ gases generated from landfill in the year i can be decreased; $\mathrm{GWP}_{\mathrm{CH}_{4}}$ and $\mathrm{GWP}_{\mathrm{CO}_{2}}$ is the Global Warming Potential (GWP) values of $\mathrm{CH}_{4}$ and $\mathrm{CO}_{2}$ gases. 


\section{Results and discursion}

\subsection{Assessment of potential solid waste generation, 2021-2030}

From the population data in 2019 [45] and the forecast of the average population growth rate per year according to [46], the estimated results of population and generated solid waste volume potential will be collected and treated in the period of 2021-2030 in the Tan Lap 1 landfill, based on the studies [47] calculated and shown in Table 2. At the same time, based on [25], the rate of solid waste collected in the period from 2021-2025 in My Tho City, Cai Be Town is $\mathrm{P}_{\text {pre }}=90 \%$ and 4 other districts in the study area are $\mathrm{P}_{\text {pre }}=85 \%$; Then, in the period from 2026-2030, the planned collection rate for the whole province will be $\mathrm{P}_{\text {pre }}=100 \%$.

Table 2. Prediction of population and MSW generation potential, in the period of 2021-2030.

\begin{tabular}{ccccccc}
\hline \multirow{2}{*}{ Year } & \multicolumn{2}{c}{ Population, Unit: people } & \multicolumn{2}{c}{ Solid waste generation potential, Unit: ton } \\
\cline { 2 - 7 } & $\begin{array}{c}\text { My Tho } \\
\text { City }\end{array}$ & $\begin{array}{c}\text { Cai Be } \\
\text { District }\end{array}$ & $\begin{array}{c}\text { Other } \\
\text { Districts }\end{array}$ & $\begin{array}{c}\text { My Tho } \\
\text { City }\end{array}$ & $\begin{array}{c}\text { Cai Be } \\
\text { District }\end{array}$ & $\begin{array}{c}\text { Other } \\
\text { Districts }\end{array}$ \\
\hline 2021 & 230,340 & 295,601 & 716,738 & 82,023 & 105,262 & 241,047 \\
2022 & 231,463 & 297,043 & 720,234 & 82,423 & 105,775 & 242,223 \\
2023 & 232,593 & 298,492 & 723,747 & 82,825 & 106,291 & 243,404 \\
2024 & 233,727 & 299,948 & 727,278 & 83,229 & 106,810 & 244,591 \\
2025 & 234,466 & 300,896 & 729,575 & 83,492 & 107,147 & 245,364 \\
2026 & 235,206 & 301,846 & 731,880 & 102,505 & 131,548 & 318,961 \\
2027 & 235,949 & 302,800 & 734,193 & 102,829 & 131,963 & 319,968 \\
2028 & 236,695 & 303,756 & 736,512 & 103,154 & 132,380 & 320,979 \\
2029 & 237,443 & 304,716 & 738,839 & 103,480 & 132,798 & 321,993 \\
2030 & 237,937 & $\mathbf{3 0 5 , 3 5 0}$ & 740,377 & 103,695 & 133,075 & 322,664 \\
\hline Total & $\mathbf{2 , 3 4 5 , 8 1 8}$ & $\mathbf{3 , 0 1 0 , 4 4 8}$ & $\mathbf{7 , 2 9 9 , 3 7 2}$ & $\mathbf{9 2 9 , 6 5 4}$ & $\mathbf{1 , 1 9 3 , 0 4 9}$ & $\mathbf{2 , 8 2 1 , 1 9 5}$ \\
\hline
\end{tabular}

The above results show that, MSW in the period 2021-2030 tends to increase continuously as follows: (i) in the period of 2021-2025, the estimated total volume of generated solid wastes collected and treated at the landfill is 2,161,905 tons (average 1,184.6 tons/day) and level (ii) in the period 2026-2030, the total volume of generated solid waste that can be treated is 2,781,993 tons (average 1,524.4 tons/day). In which, the largest generated solid waste is concentrated in Cai Be Town with a total volume of about 531,285 tons (average of 291.1 tons/day) according to the level (i) of the period 2021-2025 and about 661,764 tons (average 362.6 tons/day), according to the level (ii) of the period 2026-2030; followed by in Chau Thanh District with a total volume of about 451,527 tons (average 247.4 tons/day) according to the level (i) of the period 2021-2025 and about 595,501 tons (average 326.3 tons/day) according to level (ii) of the period 2026-2030.

\subsection{Assessment of greenhouse gas emission load}

Assuming that the composition of buried solid waste at landfill is not much different, in the period 1999-2020, from the composition of solid waste, the mass ratio ( $\mathrm{W}_{\mathrm{i}}, \%$ ) and fixed carbon composition $\left(\mathrm{DOC}_{\mathrm{i}}, \%\right)$ is shown in Table 3 and determined $\mathrm{DOC}, \mathrm{L}_{0}$ values based on studies $[21,44,48]$.

Table 3. Synthesis of buried solid waste components of Tan Lap 1 landfill.

\begin{tabular}{lcccc}
\hline Solid waste component & $\begin{array}{c}\mathbf{W}_{\mathbf{i}, \text { mean }} \\
(\mathbf{\%})\end{array}$ & $\begin{array}{c}\text { Range of DOC } \\
(\mathbf{\%})\end{array}$ & $\begin{array}{c}\mathbf{D O C}_{\mathbf{i}, \mathbf{m e a n}} \\
(\mathbf{\%})\end{array}$ & $\mathbf{W}_{\mathbf{i}} * \mathbf{D O C}_{\mathbf{i}}$ \\
\hline Organic matter & 77.53 & $20-50$ & 38 & 0.294614 \\
Paper & 3.89 & $40-50$ & 42 & 0.016338 \\
Rubber & 3.19 & 47 & 46 & 0.014674 \\
Textiles & 1.40 & $25-50$ & 28 & 0.003920 \\
\hline
\end{tabular}




\begin{tabular}{lcccc}
\hline \multicolumn{1}{c}{ Solid waste component } & $\begin{array}{c}\mathbf{W}_{\mathbf{i}}, \text { mean } \\
(\mathbf{\%})\end{array}$ & $\begin{array}{c}\text { Range of } \mathbf{D O C}_{\mathbf{i}} \\
(\mathbf{\%})\end{array}$ & $\begin{array}{c}\mathbf{D O C}_{\mathbf{i}, \text { mean }} \\
(\mathbf{\%})\end{array}$ & $\mathbf{W}_{\mathbf{i}}{ }^{*} \mathbf{D O C}_{\mathbf{i}}$ \\
\hline Nappies & 0.17 & $44-80$ & 58 & 0.000986 \\
Garden and park waste & 4.50 & $45-55$ & 48 & 0.021600 \\
Metal & 0.23 & - & - & - \\
Glass & 0.21 & - & - & - \\
Ceramic and brick & 2.14 & - & - & - \\
Hazardous waste & 0.06 & - & - & - \\
Plastics & 3.18 & - & - & - \\
Other wastes & 3.50 & - & - & - \\
\hline \multicolumn{1}{c}{ Total } & $\mathbf{1 0 0 . 0 0}$ & - & - & $\mathbf{0 . 3 5 2 1 3 2}$ \\
\hline
\end{tabular}

Similarly, it is assumed that the composition of solid waste treated at landfill is little different from year to year, continues to remain unchanged in the period 2021-2030. Combined with parameters $\mathrm{DOC}_{\mathrm{f}}=0.48$; the correction coefficient for gas $\mathrm{CH}_{4}, \mathrm{MCF}_{\mathrm{Tan}} \mathrm{Lap} 1$ $=0.6$ [48], the $\mathrm{F}$ ratio of $\mathrm{CH}_{4}$ gas in the total generated gas is valued from $50-53 \%$, the optimal $\mathrm{F}$ is determined to be $52 \%$. The results of estimating the potential value of $\mathrm{CH}_{4}$ gas generation are from $106.137-112.505 \mathrm{~m}^{3} /$ tons of solid waste with an optimal $\mathrm{L}_{0 \text {,opt(x) }}$ value of $110.3826 \mathrm{~m}^{3} /$ tons of solid waste. The optimal input $\mathrm{CH}_{4}\left(\mathrm{k}_{\mathrm{opt}}\right)$ generated rate constant for the LFG emission load forecasting model is determined by the experimental method based on the initial range of $\mathrm{k}$ values. The result of running calculation iterations determines the load, the concentration of the contagant at the measuring locations have been compared and verified to have determined the optimal $k_{\text {opt }}$ value for landfill is $k_{\text {opt }}=0.23$ year $^{-1}$. Note that the range of $\mathrm{k}$ values set in EnLandFill software for landfill is $\mathrm{k}_{\min }=0.17$ [49].

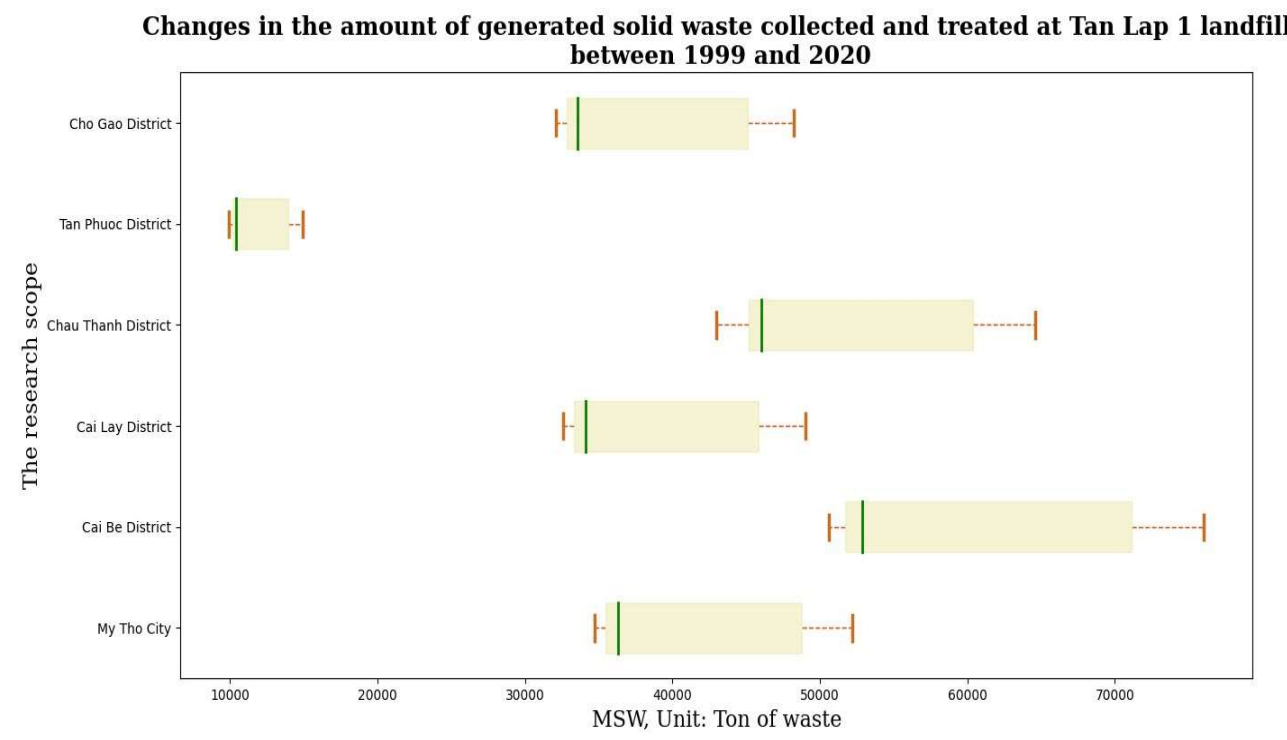

Figure 3. The diagram of changes in the solid waste generation which was collected and treated in the period of 1999-2020.

Based on the current data on the current volume of waste generated, collected and treated in the period 1999-2020 (Figure 3), it is found that in 2020 the total volume of collected and disposed urban MSW is estimated at 305,010.9 tons; in which the amount of solid waste generated in Cai Be Town is the highest with the volume of 76,034.6 tons, followed by Chau Thanh District and My Tho City with 64,569.4 tons and 52,190.5 tons respectively. The volume of solid waste generated is lowest in Tan Phuoc District with only 14,944.7 tons. The total volume of solid waste that has been buried and treated in the landfill in the period from 19992020 is 5,273,628.8 tons with the total volume of solid waste treated in Cai Be Town being the highest with 1,310,862.7 tons and the lowest is in Tan Phuoc District with 257,652.1 tons. 


\subsubsection{Scenario $1(\mathrm{~S} 1)$}

Figure 4 shows the $\mathrm{CH}_{4}, \mathrm{CO}_{2}$ and total landfill gas (TLFG) emissions load, from 20002030 under scenario 1 . Figures $4 \mathrm{a}$ and $4 \mathrm{~b}$ show that emissions of $\mathrm{CH}_{4}, \mathrm{CO}_{2}$, TLFG gases tend to increase significantly, specifically with optimal parameters $\mathrm{L}_{0}$, opt(x) $=110.38 \mathrm{~m}^{3} /$ tons solid waste (with $\mathrm{F}=52 \%$ ) and $\mathrm{k}_{\mathrm{opt}}=0.23$ year ${ }^{-1}$ determine the total accumulated $\mathrm{CH}_{4}$ and $\mathrm{CO}_{2}$ gas loads are 435.3 million $\mathrm{m}^{3}$ and 401.8 million $\mathrm{m}^{3}$ respectively out of a total of 837.0 million $\mathrm{m}^{3}$ TLFG. In particular, the highest $\mathrm{CH}_{4}$ and $\mathrm{CO}_{2}$ emissions are in 2020 with a load value of 30.9 million $\mathrm{m}^{3} \mathrm{CH}_{4} /$ year and 28.5 million $\mathrm{m}^{3}$ of $\mathrm{CO}_{2} /$ year with maximum TLFG emissions of 59.4 million $\mathrm{m}^{3} /$ year. Compared with the results using the $\mathrm{k}_{\min }$ and $\mathrm{k}_{\max }$ parameters with the calculated parameter the optimal $\mathrm{L}_{0}$, opt(x) did not change, it was found that the estimated result had a significant difference. Specifically, the total accumulated $\mathrm{CH}_{4}$ gas load reaches 395.2 million $\mathrm{m}^{3} / 760.0$ million $\mathrm{m}^{3}$ of TLFG ( $\mathrm{k}_{\min }$ case) and 512.0 million $\mathrm{m}^{3} / 984.7$ million $\mathrm{m}^{3}$ of TLFG ( $\mathrm{k}_{\max }$ case). Meanwhile, for $\mathrm{CO}_{2}$, the total cumulative load reached 364.8 million $\mathrm{m}^{3} / 760.0$ million $\mathrm{m}^{3}$ TLFG (in case of $\mathrm{k}_{\mathrm{min}}$ ) and 472.6 million $\mathrm{m}^{3} / 984.7$ million $\mathrm{m}^{3}$ TLFG (in the case of $\mathrm{k}_{\max }$ ).
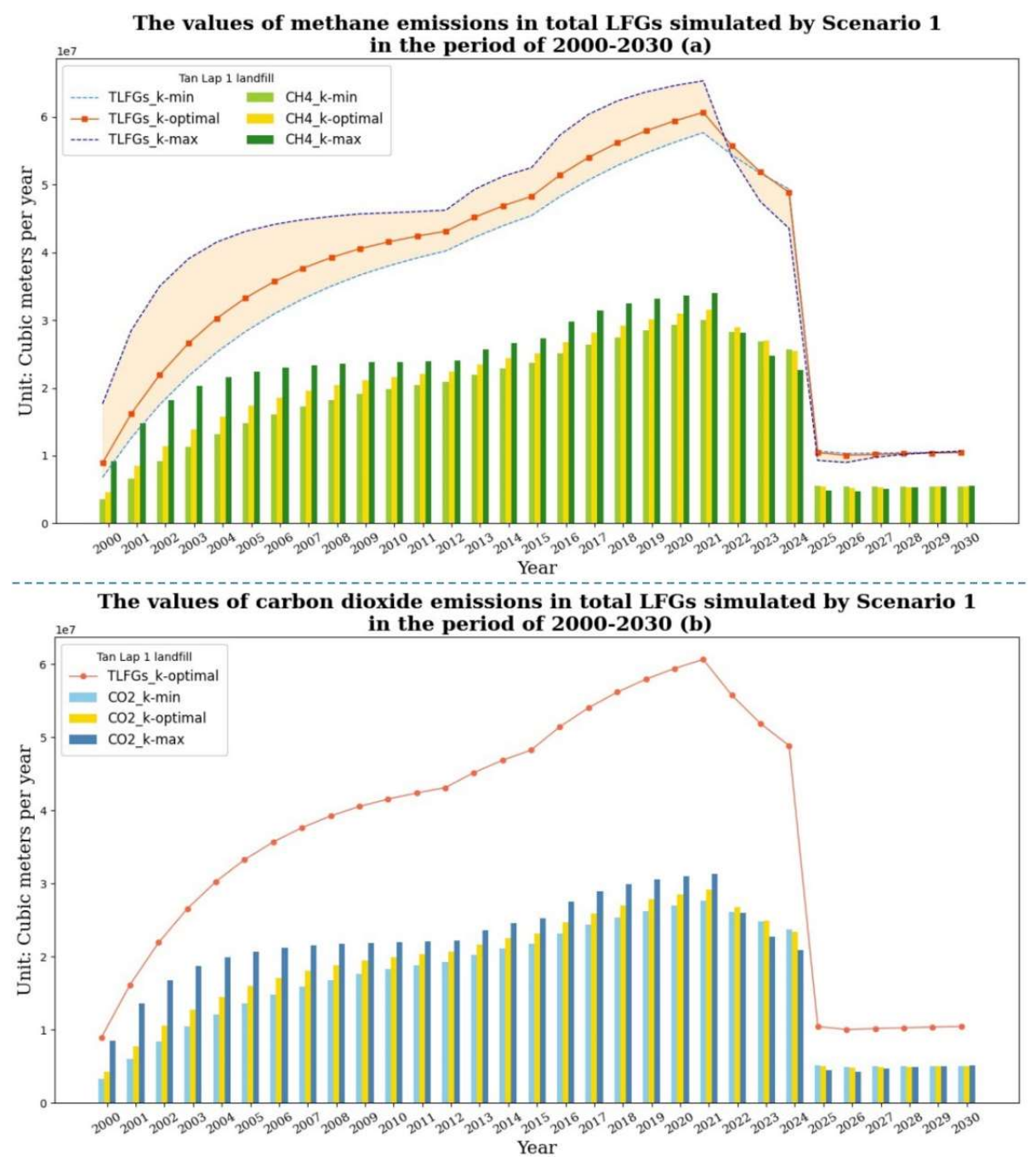

Figure 4. Emission load values of $\mathrm{CH}_{4}$ (a) \& $\mathrm{CO}_{2}$ (b) according to scenario 1 in the period of 2000-2030.

In the period 2021-2030, GHG emissions tend to decrease significantly, especially in the period 2021-2025. Specifically, from 2021 to 2025 with optimal parameters $\mathrm{L}_{0 \text {, opt (x) }}$ and $\mathrm{k}_{\text {opt }}$ identified the total cumulative load of $\mathrm{CH}_{4}$ and $\mathrm{CO}_{2}$ gases is 118.4 million $\mathrm{m}^{3} / 227.7$ 
million $\mathrm{m}^{3}$ of TLFG and 109.3 million $\mathrm{m}^{3} / 227.7$ million $\mathrm{m}^{3}$ of TLFG, respectively. In the period 2025-2030, GHG emissions tend to be stable, with little variation when landfill is installed with LFGs collection system with gas recovery efficiency of $\mathrm{E}=75 \%$, and considering the oxidation in surface coating with an oxidation index $(\mathrm{OX})$ of $10 \%$. With $\mathrm{CH}_{4}$, the total cumulative emissions are 26.7 million $\mathrm{m}^{3}$ and with $\mathrm{CO}_{2}$ of 24.7 million $\mathrm{m}^{3}$ out of a total of 51.4 million $\mathrm{m}^{3}$ of cumulative TLFG emissions, a decrease of $77.4 \%$ compared to the period 2021-2025. In the entire forecast period, the maximum generated TLFG emission load occurs at the beginning of the period in 2021 with the value of 60.7 million $\mathrm{m}^{3} /$ year, of which $\mathrm{CH}_{4}$ and $\mathrm{CO}_{2}$ are generated the highest is 31.6 million $\mathrm{m}^{3} /$ year and 29.1 million $\mathrm{m}^{3} /$ year, respectively.

\subsubsection{Scenario $2(\mathrm{~S} 2)$}

Calculation results under scenario 2 are shown in Figure 5, showing the emission load of $\mathrm{CH}_{4}, \mathrm{CO}_{2}$ gases and TLFG in the period 2000-2030. From Figures 5c and 5d show that the trend and emission load of LFGs is similar to results from scenario 1, 2000-2020, calculated based on parameters $\mathrm{L}_{0}$, opt (x) optimal, optimal $\mathrm{k}_{\mathrm{opt}}, \mathrm{k}_{\min }$ and $\mathrm{k}_{\max }$. The results show that emissions are maximized in 2020 with TFLG reaching 59.4 million $\mathrm{m}^{3} /$ year, of which $\mathrm{CH}_{4}$ reaches 30.9 million $\mathrm{m}^{3} /$ year and $\mathrm{CO}_{2}$ reaches 28.5 million $\mathrm{m}^{3} /$ year.

In the period of 2021-2030, the amount of GHGs emissions $\left(\mathrm{CH}_{4}\right.$ and $\left.\mathrm{CO}_{2}\right)$ tends to decrease significantly compared to the current state, total accumulation of TLFG decreases by about $85.32 \%$ compared to the period 2000-2020. Specifically, in the first half of the period from 2021 to 2025, emissions tended to increase slightly, from 2025 to 2026, emissions decreased sharply, then maintained almost stable until the end of the period in 2030. Maximum emissions of the entire period The forecast section occurs in 2025 with 18.0 million $\mathrm{m}^{3}$ TLFG/year, 9.4 million $\mathrm{m}^{3} \mathrm{CH}_{4}$ /year and 8.6 million $\mathrm{m}^{3} \mathrm{CO}_{2}$ /year, 3.37 times lower than scenario 1 . The period from 2021 to 2025 when the LFGs collection system is installed with the gas recovery efficiency of $\mathrm{E}=75 \%$ and the oxidation in the surface coating with an oxidation factor $(\mathrm{OX})$ of $10 \%$; together with the optimal parameters $\mathrm{L}_{0 \text {, opt (x) }}$ and $\mathrm{k}_{\mathrm{opt}}$, identified the total cumulative load of $\mathrm{CH}_{4}$ and $\mathrm{CO}_{2}$ gases of 41.7 million $\mathrm{m}^{3} \mathrm{CH}_{4} / 80.2$ million $\mathrm{m}^{3}$ TLFG and 38.5 million $\mathrm{m}^{3}$ of $\mathrm{CO}_{2} / 80.2$ million $\mathrm{m}^{3}$ TLFG, respectively, 2.84 times lower than scenario 1. In the period 2025-2030, GHGs emissions tend to be stable, with little fluctuation when the LFGs collection system increases gas recovery efficiency to $\mathrm{E}=90 \%$. With $\mathrm{CH}_{4}$, the total cumulative emission load is 22.2 million $\mathrm{m}^{3}$ and for $\mathrm{CO}_{2}$ gas is 20.5 million $\mathrm{m}^{3}$ out of a total of 42.7 million $\mathrm{m}^{3}$ of accumulated TLFG emissions, a decrease of $46.8 \%$ compared to the period 2021-2025 and 1.21 times lower than scenario 1.

\subsubsection{Scenario $3(\mathrm{~S} 3)$}

The emission load of $\mathrm{CH}_{4}, \mathrm{CO}_{2}$ gases and TLFG for the period 2000-2030 under scenario 3 is shown in Figure 6. Figures 6e and 6f show that the emission trend of LFGs is similar to the simulation results of scenario 1 as well as scenario 2. Cumulative emissions generated in the period 2000-2020 with TFLG reaching 837.0 million $\mathrm{m}^{3}, 77.1$ million $\mathrm{m}^{3}$ higher for the case of $\mathrm{k}_{\min }$ and 147.6 lower million $\mathrm{m}^{3}$ in the case of $\mathrm{k}_{\max }$; of which $\mathrm{CH}_{4}$ reached 435.3 million $\mathrm{m}^{3}$, higher than 40.1 million $\mathrm{m}^{3}$ with the case of $\mathrm{k}_{\min }$ and lower than 76.8 million $\mathrm{m}^{3}$ with the case of $\mathrm{k}_{\max }$ and for $\mathrm{CO}_{2}, 37.0$ higher million $\mathrm{m}^{3}$ for $\mathrm{k}_{\min }$ case and lower than 70.9 million $\mathrm{m}^{3}$ for $\mathrm{k}_{\max }$ case.

In the period of 2021-2030, the value of GHGs emission load of $\mathrm{CH}_{4}$ and $\mathrm{CO}_{2}$ tends to decrease significantly compared to the current state, the total accumulation of TLFG decreases by about $86.59 \%$ compared to the period 2000-2020. Specifically, in the first half of the period from 2021-2025, emissions tended to increase slightly, from 2025 to 2026, emissions decreased sharply, then maintained almost stable until the end of the period in 2030. Considering the entire forecast period, the maximum emissions will occur in 2025 with 
16.1 million $\mathrm{m}^{3}$ of TLFG/year, 8.4 million $\mathrm{m}^{3}$ of $\mathrm{CH}_{4} /$ year and 7.7 million $\mathrm{m}^{3}$ of $\mathrm{CO}_{2} /$ year, 1.12 times lower than the scenario 2, 3.77 times compared to scenario 1 . In the first half of the forecast period from 2021 to 2025, LFGs collection system is installed with the gas recovery efficiency of $E=75 \%$ and oxidation in the surface coating with an oxidation

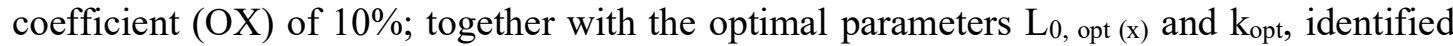
the total cumulative $\mathrm{CH}_{4}$ and $\mathrm{CO}_{2}$ loads is 39.0 million $\mathrm{m}^{3} \mathrm{CH}_{4} / 75.0$ million $\mathrm{m}^{3}$ TLFG and 36.0 million $\mathrm{m}^{3} \mathrm{CO}_{2} / 75.0$ million $\mathrm{m}^{3} \mathrm{TLFG}$, respectively, 1.07 times lower than scenario 2 and 3.04 times lower than scenario 1. In the second half period from 2025 to 2030, GHGs emissions tend to be stable, there is an increase but less variation when the LFGs collection system increases gas recovery efficiency to $\mathrm{E}=90 \%$. With $\mathrm{CH}_{4}$, the total cumulative emission load is 19.3 million $\mathrm{m}^{3}$ and with $\mathrm{CO}_{2}$ is 17.8 million $\mathrm{m}^{3}$ out of a total of 37.2 million $\mathrm{m}^{3}$ of accumulated TLFG emissions, a decrease of 50.4\% compared to the period 2021-2025, 1.15 times lower than scenario 2 and 1.38 times lower than scenario 1.
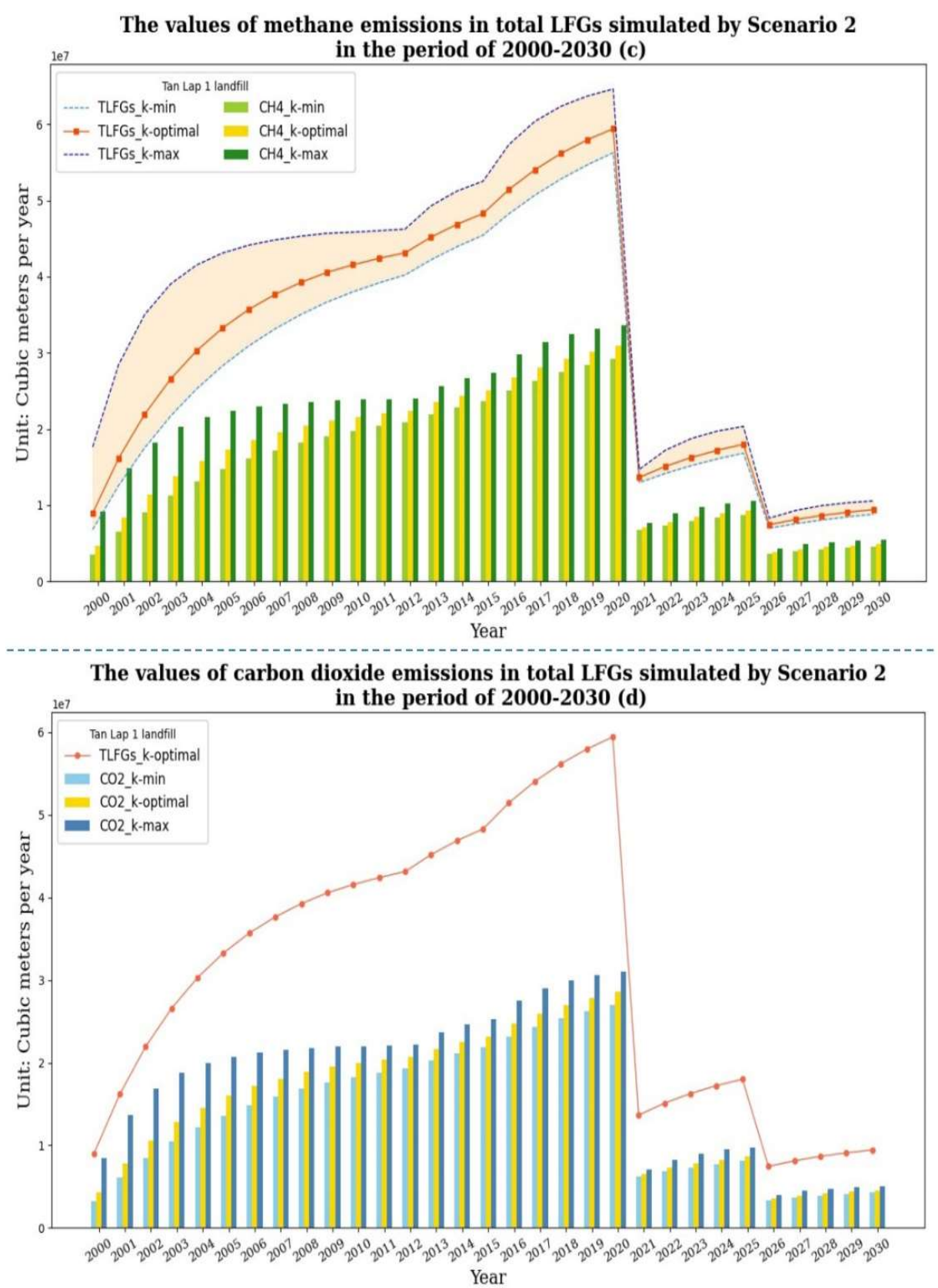

Figure 5. Emission load values of $\mathrm{CH}_{4}$ (c) \& $\mathrm{CO}_{2}$ (d) according to scenario 2 in the period of 2000-2030. 

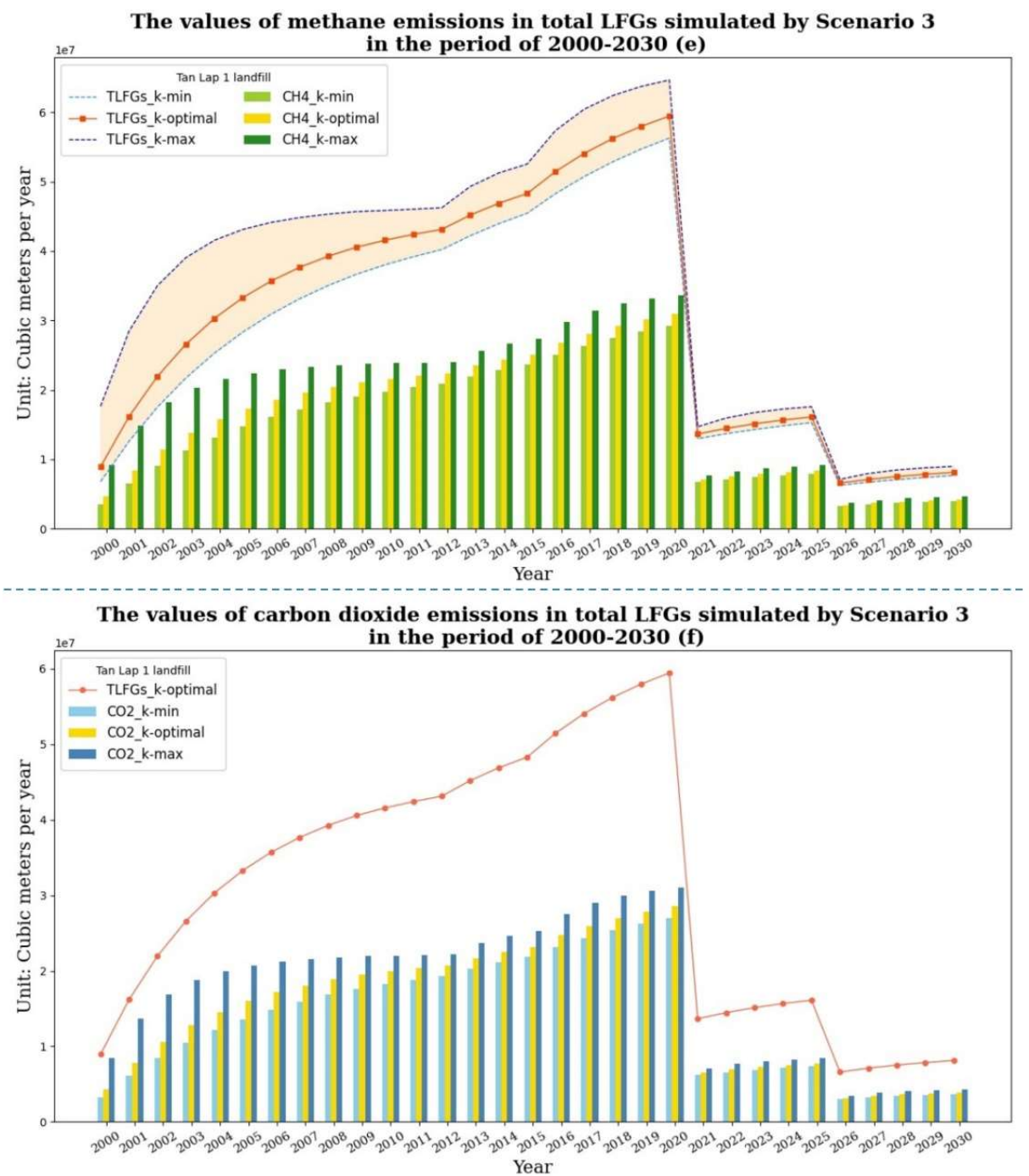

Figure 6. Emission load values of $\mathrm{CH}_{4}$ (e) \& $\mathrm{CO}_{2}$ (f) according to scenario 3 in the period of 2000-2030.

\subsection{Assessing the potential for electricity creation}

\subsubsection{Electricity output from recovered biogas in the period 2021-2030}

The result of estimation of total $\mathrm{CH}_{4}$ emission load recovered from the collection system with recovery efficiency $E=75-90 \%$ under scenarios $1-3$, potential value of annual electricity generation $\mathrm{EP}_{\mathrm{LFG}, \text { yeari }}(\mathrm{kWh} /$ year) was estimated using formula (2) shown in Table 4. Comment that, the annual electricity generation potential, 2021-2030, is highest in scenario 2, with a total value of 806.16-999.64 million $\mathrm{kWh}, 3.37$ times higher than scenario 1 and 1.12 times higher than scenario 3. The greatest potential for electricity generation is in 2030 with an estimated 109.46-135.72 million $\mathrm{kWh} /$ year. The total value of electricity generated annually in scenarios 1 and 3 is $239.11-296.50$ million $\mathrm{kWh}, 721.59-894.77$ million $\mathrm{kWh}$, respectively. The lowest power generation potential can be seen in scenario 1, about 3.02 times lower than scenario 3 . The largest power generation potential in scenarios 1 and 3 is in 2030, estimated to be 40.48 50.20 million $\mathrm{kWh} /$ year (scenario 1) and 94.24-116.85 million $\mathrm{kWh} /$ year (scenario 3).

The size of the generating station $\left(\mathrm{LFGTE}_{(\text {size) }}\right)$ is calculated according to the formula (3) from $\mathrm{CH}_{4}$ with the assumption that the power station is capable of operating throughout the year with $D_{h r}=24$ hours/day, the number of days the power station operates in a year $\gamma=365$ days. Thus, with the above assumptions, in scenario 1, the scale of the power station will 
gradually increase from 4,620 to 5,728 MW in 2025, it can reach 4,621-5,730 MW in 2030 . For scenario 2, the scale of the power station from 6,028-7,475 MW in 2021 has increased significantly by about 2.07 times by the end of the period, estimated at 12,495-15,494 MW by 2030 . Similarly for scenario 3, the size of power station tends to increase gradually in the whole period, from 6,028-7,475 MW (in 2021) up to 10,757-13,339 MW, by 2030.

Table 4. Estimated electricity generated potential results in the period 2021-2030.

\begin{tabular}{|c|c|c|c|c|c|}
\hline \multirow[t]{2}{*}{ Year } & \multirow[b]{2}{*}{$\begin{array}{l}\mathrm{CAP}_{\mathrm{CH}_{4 \text { Yeari }}} \\
\text { (million } \\
\mathrm{m}^{3} / \text { year) }\end{array}$} & \multicolumn{4}{|c|}{ Electricity generation potential, Unit: million $\mathrm{kWh} / \mathrm{year}$} \\
\hline & & $\begin{array}{c}\text { LHV }=35 \\
\mathrm{MJ} / \mathrm{m}^{3} \\
\varepsilon=30 \%\end{array}$ & $\begin{array}{c}\text { LHV }=35 \\
\mathrm{MJ} / \mathrm{m}^{3} \\
\varepsilon=35 \%\end{array}$ & $\begin{array}{c}\mathrm{LHV}=37.2 \\
\mathrm{MJ} / \mathrm{m}^{3} \\
\varepsilon=30 \% \\
\end{array}$ & $\begin{array}{c}\text { LHV }=37.2 \\
\mathrm{MJ} / \mathrm{m}^{3} \\
\varepsilon=35 \%\end{array}$ \\
\hline \multicolumn{6}{|c|}{ Scenario 1} \\
\hline 2021 & 0.000 & 0.000 & 0.000 & 0.000 & 0.000 \\
\hline 2022 & 0.000 & 0.000 & 0.000 & 0.000 & 0.000 \\
\hline 2023 & 0.000 & 0.000 & 0.000 & 0.000 & 0.000 \\
\hline 2024 & 0.000 & 0.000 & 0.000 & 0.000 & 0.000 \\
\hline 2025 & 16.323 & 40.467 & 47.212 & 43.011 & 50.179 \\
\hline 2026 & 15.670 & 38.848 & 45.323 & 41.290 & 48.172 \\
\hline 2027 & 15.876 & 39.358 & 45.918 & 41.832 & 48.805 \\
\hline 2028 & 16.050 & 39.791 & 46.423 & 42.292 & 49.341 \\
\hline 2029 & 16.200 & 40.161 & 46.855 & 42.686 & 49.800 \\
\hline 2030 & 16.329 & 40.483 & 47.230 & 43.027 & 50.199 \\
\hline $\begin{array}{c}\text { Total } \\
(\text { million } \mathrm{kWh}) \\
\end{array}$ & 96.447 & 239.109 & 278.960 & 254.138 & 296.495 \\
\hline \multicolumn{6}{|c|}{ Scenario 2} \\
\hline 2021 & 21.299 & 52.804 & 61.605 & 56.123 & 65.477 \\
\hline 2022 & 23.556 & 58.399 & 68.132 & 62.070 & 72.415 \\
\hline 2023 & 25.381 & 62.924 & 73.412 & 66.880 & 78.026 \\
\hline 2024 & 26.864 & 66.601 & 77.701 & 70.787 & 82.585 \\
\hline 2025 & 28.075 & 69.603 & 81.203 & 73.978 & 86.307 \\
\hline 2026 & 34.870 & 86.449 & 100.857 & 91.882 & 107.196 \\
\hline 2027 & 37.982 & 94.164 & 109.857 & 100.082 & 116.763 \\
\hline 2028 & 40.487 & 100.374 & 117.103 & 106.683 & 124.464 \\
\hline 2029 & 42.510 & 105.389 & 122.954 & 112.013 & 130.682 \\
\hline 2030 & 44.150 & 109.455 & 127.697 & 116.335 & 135.724 \\
\hline $\begin{array}{c}\text { Total } \\
\text { (million } \mathrm{kWh})\end{array}$ & 325.174 & 806.160 & 940.520 & 856.833 & 999.639 \\
\hline \multicolumn{6}{|c|}{ Scenario 3} \\
\hline 2021 & 21.299 & 52.804 & 61.605 & 56.123 & 65.477 \\
\hline 2022 & 22.561 & 55.932 & 65.254 & 59.448 & 69.356 \\
\hline 2023 & 23.591 & 58.486 & 68.234 & 62.162 & 72.523 \\
\hline 2024 & 24.437 & 60.583 & 70.681 & 64.391 & 75.123 \\
\hline 2025 & 25.137 & 62.319 & 72.705 & 66.236 & 77.275 \\
\hline 2026 & 30.853 & 76.491 & 89.239 & 81.299 & 94.849 \\
\hline 2027 & 33.249 & 82.430 & 96.169 & 87.612 & 102.213 \\
\hline 2028 & 35.180 & 87.218 & 101.754 & 92.700 & 108.150 \\
\hline 2029 & 36.742 & 91.090 & 106.272 & 96.816 & 112.952 \\
\hline 2030 & 38.011 & 94.236 & 109.942 & 100.159 & 116.852 \\
\hline $\begin{array}{c}\text { Total } \\
\text { (million } \mathrm{kWh}) \\
\end{array}$ & 291.061 & 721.589 & 841.854 & 766.946 & 894.770 \\
\hline
\end{tabular}




\subsubsection{Assessment of annual alternative coal output and $\mathrm{CO}_{2}$ mitigation}

Using recovered $\mathrm{CH}_{4}$ gas as a fuel source for electricity production is an alternative to coal material, while reducing the amount of $\mathrm{CO}_{2}$ caused (Table 5), calculated by formula (4). The assumption of the lower heating values of coal, $\operatorname{LHV}_{\text {coal(wet basis) }}=22.732 \mathrm{MJ} / \mathrm{kg}[35,50,51]$; Boiler efficiency from coal burning can be achieved as $\eta=75 \%$ [50] and operating time is $\tau=$ 24 hours provided that the boiler operates throughout 365 days/year. On the one hand, results from scenario 1 show that the output of replaced coal is estimated at 18,429-22,851 tons in the period of 2021-2030 (average about 1,843-2,285 tons/year), specifically increasing from 2025 with about 3,119-3,867 tons/year up to 3,120-3,869 tons/year in 2030. For scenario 2, there are about 62,132-77,044 tons of coal (average about 6,213-7,704 tons/year) saved when using LFG instead in the period of 2021-2030, the trend of gradually increasing from 4,070 to 5,046 tons/year (by 2021) up to 8,436-10,460 tons/year (in 2030). Similarly for scenario 3, the potential reduction of coal used in the above period is estimated at 55,614-68,962 tons (average about 5,561-6,896 tons/year) and gradually increasing in the period from 2021 with 4,070 5,046 tons/year to 7,263-9,006 tons/year by 2030 .

On the other hand, the total amount of carbon dioxide $\left(\mathrm{CO}_{2}\right)$ avoided when emissions into the atmosphere due to the amount of coal replaced is also evaluated for the period 2021-2030; accordingly, the total value is approximately $67,571-83,789$ tons of $\mathrm{CO}_{2}$ for scenario 1 (average about $6,757-8,379$ tons of $\mathrm{CO}_{2} /$ year), about $222,819-282,495$ tons of $\mathrm{CO}_{2}$ for scenario 2 (average about 22,782-28,250 tons of $\mathrm{CO}_{2} /$ year) and about 203,919-252,860 tons of $\mathrm{CO}_{2}$ for scenario 3 (average about 20,392-25,286 tons of $\mathrm{CO}_{2} /$ year).

Table 5. Estimated alternative coal and $\mathrm{CO}_{2}$ minimization potential results in the period 2021-2030.

\begin{tabular}{ccccccc}
\hline & \multicolumn{2}{c}{ Scenario 1 } & \multicolumn{2}{c}{ Scenario 2 } & \multicolumn{2}{c}{ Scenario 3 } \\
\cline { 2 - 7 } Year & $\begin{array}{c}\mathbf{m}_{\text {coal }} \\
\text { (Unit: } \\
\text { ton/year) }\end{array}$ & $\begin{array}{c}\mathbf{C O}_{2} \\
\text { reduction } \\
\text { (Unit: } \\
\text { ton/year) }\end{array}$ & $\begin{array}{c}\text { mcoal } \\
\text { (Unit: } \\
\text { ton/year) }\end{array}$ & $\begin{array}{c}\mathbf{C O}_{\mathbf{2}} \\
\text { reduction } \\
\text { (Unit: } \\
\text { ton/year) }\end{array}$ & $\begin{array}{c}\text { mcoal } \\
\text { (Unit: } \\
\text { ton/year) }\end{array}$ & $\begin{array}{c}\mathbf{C O}_{2} \\
\text { reduction } \\
\text { (Unit: } \\
\text { ton/year) }\end{array}$ \\
\hline 2021 & 0,000 & 0,000 & 5,046 & 18,504 & 5,046 & 18,504 \\
2022 & 0,000 & 0,000 & 5,581 & 20,464 & 5,345 & 19,600 \\
2023 & 0,000 & 0,000 & 6,014 & 22,050 & 5,589 & 20,495 \\
2024 & 0,000 & 0,000 & 6,365 & 23,338 & 5,790 & 21,230 \\
2025 & 3,867 & 14,181 & 6,652 & 24,390 & 5,956 & 21,838 \\
2026 & 3,713 & 13,613 & 8,262 & 30,293 & 7,310 & 26,804 \\
2027 & 3,761 & 13,792 & 8,999 & 32,997 & 7,878 & 28,885 \\
2028 & 3,803 & 13,944 & 9,593 & 35,173 & 8,335 & 30,563 \\
2029 & 3,838 & 14,073 & 10,072 & 36,930 & 8,705 & 31,920 \\
2030 & 3,869 & 14,186 & 10,460 & 38,355 & 9,006 & 33,022 \\
\hline Total & $\mathbf{2 2 , 8 5 1}$ & $\mathbf{8 3 , 7 8 9}$ & $\mathbf{7 7 , 0 4 4}$ & $\mathbf{2 8 2 , 4 9 5}$ & $\mathbf{6 8 , 9 6 2}$ & $\mathbf{2 5 2 , 8 6 0}$ \\
\hline
\end{tabular}

\subsubsection{Greenhouse gas emission reduction potential}

To evaluate the potential for $\mathrm{GHG}$ emission reduction, including $\mathrm{CH}_{4}$ and $\mathrm{CO}_{2}$, the index of GWP is considered. The estimated results are detailed in Figure 7.

For scenario 1, GHG emission reduction potential is calculated with recovery efficiency $\mathrm{E}=75 \%$ because in the period of 2021-2024, recovery of generated LFGs has not been considered. Total estimated mitigation potential $\sum \mathrm{RE}_{\mathrm{GHGs}, \mathrm{re}}=1,962.61$ thousand tons of $\mathrm{CO}_{2}$-eq compared with without recovery of $\mathrm{LFG}$ is $\sum \mathrm{RE}_{\mathrm{GHGs}, \mathrm{no}-\mathrm{re}}=2,910.54$ thousand tons of $\mathrm{CO}_{2}$-eq, increasing from 2025 to 2030 with 319.19 thousand tons of $\mathrm{CO}_{2}-$ eq/year up to 332.62 thousand tons of $\mathrm{CO}_{2}-\mathrm{eq} /$ year. With scenario 2, the total GHG emission reduction potential for the entire period 2021-2030 $\sum \mathrm{RE}_{\mathrm{GHGs}, \mathrm{re}}=6,623.74$ thousand tons of $\mathrm{CO}_{2}$-eq 
compared to without recovering LFG is $\sum \mathrm{RE}_{\mathrm{GHGs}, \mathrm{no}-\mathrm{re}}=8,807.04$ thousand tons of $\mathrm{CO}_{2}-\mathrm{eq}$, increasing Gradually from 2021 with 433.86 thousand tons of $\mathrm{CO}_{2}-$ eq/year up to 899.32 thousand tons of $\mathrm{CO}_{2}-$ eq/year by 2030. Under scenario 3, the total $\mathrm{GHG}$ emission reduction potential for the entire period of 2021-2030: $\sum \mathrm{RE}_{\mathrm{GHGs}, \mathrm{re}}=5,928.87$ thousand tons of $\mathrm{CO}_{2}-$ eq compared to without recovering $\mathrm{LFG}$ is $\sum \mathrm{RE}_{\mathrm{GHGs}, \mathrm{no}-\mathrm{re}}=7,908.18$ thousand tons of $\mathrm{CO}_{2}-$ eq; GHG emission reduction potential increases from 433.86 thousand tons $\mathrm{CO}_{2}$-eq/year (in 2021 ) to 774.28 thousand tons of $\mathrm{CO}_{2}-\mathrm{eq} /$ year (in 2030).

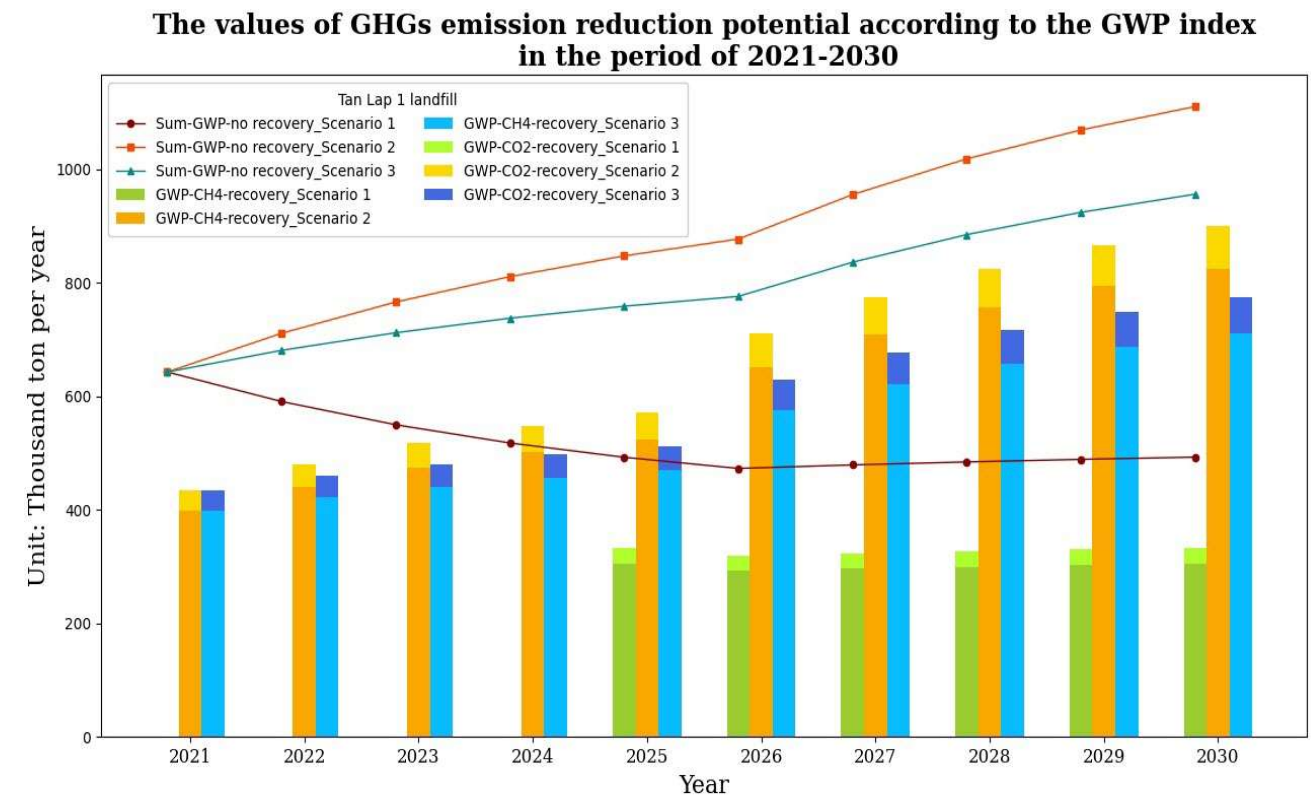

Figure 7. Potential value of GHG emission reduction, period 2021-2030 through GWP index.

\subsection{EnLandFill model validation}

The results of the calculation of the Nash-Sutcliffe index (NSE) show the simulation efficiency of EnLandFill ver. 2019 software in determining the emission load of generated gases, TLFG, $\mathrm{CH}_{4}$ and $\mathrm{CO}_{2}$ from the study area. The NSE is estimated based on the monitoring results of $\mathrm{CH}_{4}$ gas concentrations collected at 08:00-11:00 on 25/03, 10/06, 10/09, 11/11 of 02 years 2018 and 2019 from [26-27] at the TL1-TG monitoring position within the scope of the research area. The results of simulations of the spread of $\mathrm{CH}_{4}$ gas at the above calculation times from the study area based on the estimation results from the emission load module (scenarios 1, 2 and 3) in the EnLandFill software (Figure 8) were also extracted respectively at locations and at the same time of respective assessment.

With the Nash-Sutcliffe index (NSE), for simulation as $\mathrm{NSE}_{\text {TanLap } 1}=0.836>0.7$, respectively, showed that the simulation results by EnLandFill software were at a good level with the condition that NSE $>0.7$ was satisfied. Table 6 and Figure 9 show the comparison between the results of $\mathrm{CH}_{4}$ gas concentration between monitoring and simulated $\mathrm{CH}_{4}$ concentration using EnLandFill software. 

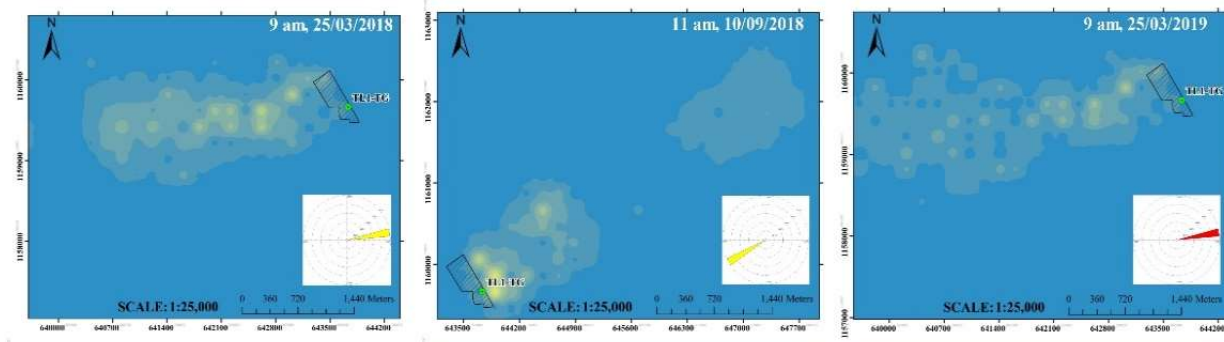

Methane concentration (Unit: microgram/cubic meter) $0.000-6.619$ $6.620-19.856$

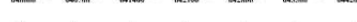
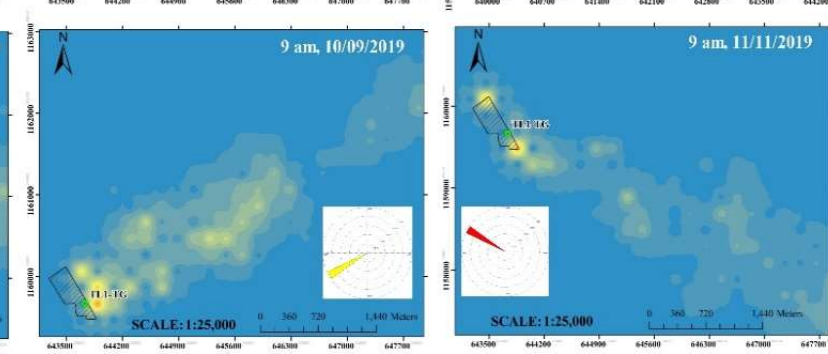
$19.857-33.093$
$33,694-48.537$
$48.538-66.187$

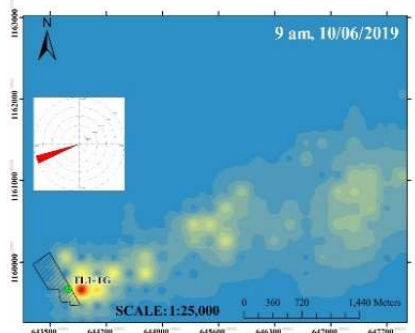

$\square 6.188-90.455$

$90.456-119.136$ $\square \quad 152.230-185.323$ $152.230-185.323$
$\square \quad 185.324-218.416$ $\square 218.417-258.128$ $\square 258.129-300.046$ \300.047- 337.552 $\square 337.553-372.851$ $372.852-405.945$
$\square$ $405.946-447.863$ $405.946-447.863$
$-447.864-498.606$ $447.864-498.606$
$-498.607-562.586$

Figure 8. Maps of simulating $\mathrm{CH}_{4}$ concentration dispersion levels and scope for several different times in 2018 and 2019.

Table 6. Table comparing $\mathrm{CH}_{4}$ concentrations between monitoring and simulation using the EnLandFill software.

\begin{tabular}{|c|c|c|c|c|c|}
\hline \multirow[t]{2}{*}{ Signs } & \multicolumn{2}{|c|}{$\begin{array}{c}\text { Coordinates of } \\
\text { monitoring stations }\end{array}$} & \multirow[t]{2}{*}{$\begin{array}{l}\text { Monitoring time, } \\
\text { (hour) }\end{array}$} & \multirow{2}{*}{$\begin{array}{c}\text { Simulating } \mathrm{CH}_{4} \\
\text { concentration by } \\
\text { EnLandFill, }\left(\mu \mathrm{g} / \mathrm{m}^{3}\right)\end{array}$} & \multirow{2}{*}{$\begin{array}{c}\text { Monitoring } \\
\mathrm{CH}_{4} \\
\text { concentration, } \\
\left(\mu \mathrm{g} / \mathrm{m}^{3}\right)\end{array}$} \\
\hline & $X(m)$ & $Y(m)$ & & & \\
\hline TL1-TG & 643733.41 & 1159665.13 & 9 am-25/03/2018 & 72.73 & 80.00 \\
\hline TL1-TG & 643733.41 & 1159665.13 & 8 am-10/06/2018 & 93.09 & 83.00 \\
\hline TL1-TG & 643733.41 & 1159665.13 & $11 \mathrm{am}-10 / 09 / 2018$ & 29.33 & 58.90 \\
\hline TL1-TG & 643733.41 & 1159665.13 & 9 am-25/03/2019 & 16.74 & 9.80 \\
\hline TL1-TG & 643733.41 & 1159665.13 & 9 am-10/06/2019 & 16.78 & 11.80 \\
\hline TL1-TG & 643733.41 & 1159665.13 & 9 am-10/09/2019 & 16.76 & 13.60 \\
\hline TL1-TG & 643733.41 & 1159665.13 & 9 am-11/11/2019 & 16.76 & 9.50 \\
\hline
\end{tabular}

CH4 concentration comparison of simulating and monitoring at the TL1-TG observing station in the Tan Lap 1 landfill, Tien Giang province

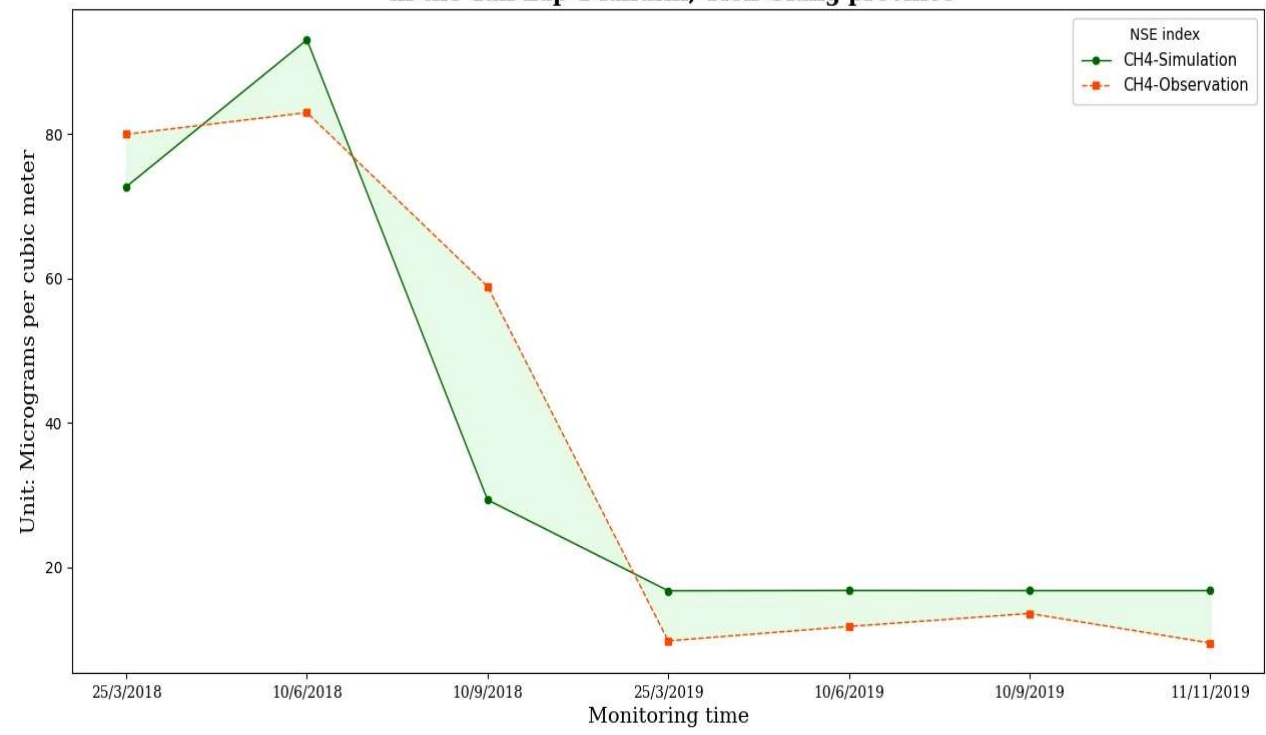

Figure 9. Comparison of $\mathrm{CH}_{4}$ concentrations between monitoring and simulation at measuring locations. 


\section{Conclusion}

The study identified the optimal calculation parameters and quantified the load of LFG emissions, including total LFGs, $\mathrm{CH}_{4}$ and $\mathrm{CO}_{2}$, forecast for the period 2021-2030, carried out for case studies in Tien Giang province. The main results of this paper are shown as follows.

In the period of 2021-2030, landfill is considered to have the lowest accumulation of GHG, $\mathrm{CH}_{4}$ and $\mathrm{CO}_{2}$ emissions in scenario 3, estimated about 58 million $\mathrm{m}^{3} \mathrm{CH}_{4}$ and 53 million $\mathrm{m}^{3} \mathrm{CO}_{2}$, showing the potential of mitigation GHG emissions according to the GWP index are approximate 6 million tons of $\mathrm{CO}_{2}$-eq. The predicted maximum emission year is 2025 with a load of 8.4 million $\mathrm{m}^{3} \mathrm{CH}_{4} /$ year and 7.7 million $\mathrm{m}^{3}$ of $\mathrm{CO}_{2} /$ year with a GWP of over 750 thousand tons of $\mathrm{CO}_{2}$-eq. The highest accumulated $\mathrm{GHG}$ emissions are in scenario 1, estimated roughly 150 million $\mathrm{m}^{3} \mathrm{CH}_{4}$ and 134 million $\mathrm{m}^{3}$ of $\mathrm{CO}_{2}$, indicating that GWP index reaches around 2 million tons of $\mathrm{CO}_{2}$-eq. The maximum emission year is 2021 with a discharge of over 30 million $\mathrm{m}^{3} \mathrm{CH}_{4} /$ year and 29 million $\mathrm{m}^{3}$ of $\mathrm{CO}_{2} /$ year with a GWP of about 650 thousand tons of $\mathrm{CO}_{2}-$ eq. The research results also show that with gas recovery efficiency generated from $75-90 \%$ designed for 3 scenarios, in the period of 2021-2030, it is expected to generate a total potential electricity production capacity estimated up to 990 million $\mathrm{kWh}$ is equivalent to the potential of replacing coal fuel source, from about 18,500 77,000 thousand tons and about 67,500-283,000 thousand tons of $\mathrm{CO}_{2}$ avoided from coal burning.

The study results show that planning according to scenario 3 will be optimal for the treatment of MSW in Tien Giang province. This is the scenario with the lowest cumulative GHG emissions and also potentially significant power generation in the study area, 2021-2030. In addition, the simulation efficiency of the software is quite good with the NSE statistic index above 0.80 . However, insufficient measurement data is one of the important reasons affecting the predictive errors of the model. Thus, future studies will continue to use the latest monitoring data to verify the simulation results by careful take into consideration background concentrations and pollution contributions from other areas in the treatment area, in order to make more accurate forecast results of the emission load of LFGs, in special attention, is paid to $\mathrm{CH}_{4}$ gas.

Author contribution statement: Conceived and designed the experiments; Analyzed and interpreted the data; contributed reagents, materials, analysis tools or data; manuscript editing: B.T.L.; Performed the experiments; contributed reagents, materials, analyzed and interpreted the data, wrote the draft manuscript: N.H.P.

Acknowledgements This research was funded by the Viet Nam National University Ho Chi Minh City (VNU-HCM), grant No: B2019-20B-01. The authors would also like to thank the members of the Laboratory for Environmental Modelling, Ho Chi Minh City University of Technology for discussions that improved the quality of the publication.

Competing interest statement The authors declare no conflict of interest.

\section{References}

1. Berenyi, E.B.; Gould, R.N. Methane recovery from municipal landfills in the USA. Waste Manag. Res. 1986, 4, 189-196.

2. IPCC. Climate Change 2007: Synthesis Report. Intergov. Panel Clim. Chang. 2007, pp. 1-104.

3. EU Commission. Taking Sustainable use of resources forward: A Thematic Strategy on the prevention and recycling of waste, Brussels, Belgium, 2005.

4. Huhtinen, K.; Lilja, R.; Sokka, L.; Salmenperä, H.; Runsten, S. The National Waste Plan to the Year 2016 - Background Document, 2007.

5. Finland Ministry of the Environment. Towards a Recycling Society e National Waste 
Plan until 2016 (in Finland), 2010.

6. Niskanen, A.; Värri, H.; Havukainen, J.; Uusitalo, V.; Horttanainen, M. Enhancing landfill gas recovery. J. Clean. Prod. 2013, 55, 67-71.

7. Aghdam, E.F.; Fredenslund, A.M.; Chanton, J.; Kjeldsen, P.; Scheutz, C. Determination of gas recovery efficiency at two Danish landfills by performing downwind methane measurements and stable carbon isotopic analysis. Waste Manag. 2018, 73, 220-229.

8. Spokas, K.; Bogner, J.; Chanton, J.P.; Morcet, M.; Aran, C.; Graff, C.; Golvan, Y.M.L.; Hebe, I. Methane mass balance at three landfill sites : What is the efficiency of capture by gas collection systems?. Waste Manage. 2006, 26, 516-525.

9. Cudjoe, D.; Han, M.S.; Nandiwardhana, A.P. Electricity generation using biogas from organic fraction of municipal solid waste generated in provinces of China: Techno-economic and environmental impact analysis. Fuel Process. Technol. 2020, 203, 106381.

10. US EPA. Landfill Methane Outreach Program: Accomplishments, 2008.

11. US EPA. Landfill Methane Outreach Program: Basic Information, 2008.

12. US EPA. Landfill Methane Outreach Program: Energy Projects and Candidate Landfills, 2008.

13. Ghosh, P. et al. Assessment of methane emissions and energy recovery potential from the municipal solid waste landfills of Delhi, India. Bioresour. Technol. 2019, 611615.

14. Menikpura, S.N.M.; Sang-Arun, J.; Bengtsson, M. Climate co-benefits of energy recovery from landfill gas in developing Asian cities: A case study in Bangkok. Waste Manag. Res. 2013, 31, 1002-1011.

15. Duc, N.H. Current status, solid waste management policy in Vietnam and potential for energy recovery from solid waste, Ho Chi Minh City, 2014.

16. World Bank. Background Paper-Potential climate change mitigation opportunities in waste management sector in Vietnam, 2009.

17. UNFCCC. Report Landfill gas recovery and utilization in Nam Son, Tay Mo landfills in Hanoi (Clean Development Mechanism - CDM) - Project 3733, 2018.

18. Schneider, P.; Anh, L.H.; Wagner, J.; Reichenbach, J.; Hebner, A. Solid waste management in Ho Chi Minh City, Vietnam: Moving towards a circular economy? Sustain. 2017, 9, 1-20.

19. Biwase, Make electricity from waste, Binh Duong Water - Environment Joint Stock Company (Biwase), 2020.

20. People's Committee of Tien Giang Province. Report on solid waste management in Tien Giang, Tien Giang Province, 2019.

21. Long, B.T.; Phong, N.H. Integrated model for methane emission and dispersion assessment from landfills: A case study of Ho Chi Minh City, Vietnam. Sci. Total Environ. 2020, 738, 139865.

22. Lima, R.M. et al. Spatially distributed potential of landfill biogas production and electric power generation in Brazil. Waste Manag. 2018, 74, 323-334.

23. Cudjoe, D.; Han, M.S. Economic and environmental assessment of landfill gas electricity generation in urban districts of Beijing municipality. Sustain. Prod. Consum. 2020, 23, 128-137.

24. Cudjoe, D.; Han, M.S.; Chen, W. Power generation from municipal solid waste landfilled in the Beijing-Tianjin-Hebei region. Energy 2021, 217, 119393.

25. People's Committee of Tien Giang Province. Planning of Solid waste management in Tien Giang Province for the period 2011 - 2020, vision to 2030, Tien Giang Province, 2013.

26. Tien Giang Department of Natural Resources and Environment. Report on the results 
of environmental monitoring in Tien Giang province in 2018, Tien Giang province, 2018.

27. Tien Giang Department of Natural Resources and Environment. Report on the results of environmental monitoring in Tien Giang province in 2019. Tien Giang province, 2019.

28. Scarlat, N.; Motola, V.; Dallemand, J.F.; Monforti-Ferrario, F.; Mofor, L. Evaluation of energy potential of Municipal Solid Waste from African urban areas. Renew. Sustain. Energy Rev. 2015, 50, 1269-1286.

29. Ayodele, T.R.; Ogunjuyigbe, A.S.O.; Ekoh, E.E. Outlook of Agricultural Sector in the Face of Changing Global Climate: The Case of Nigeria. Agric. Res. Technol. Open Access J. 2017, 5, 68-71.

30. Ogunjuyigbe, A.S.O.; Ayodele, T.R.; Alao, M.A. Electricity generation from municipal solid waste in some selected cities of Nigeria: An assessment of feasibility, potential and technologies. Renew. Sustain. Energy Rev. 2017, 80, 149-162.

31. Ayodele, T.R.; Ogunjuyigbe, A.S.O.; Alao, M.A. Economic and environmental assessment of electricity generation using biogas from organic fraction of municipal solid waste for the city of Ibadan, Nigeria, J. Clean. Prod. 2018, 203, 718-735.

32. Anh, T.T. Evaluation of coal types used for thermal power plants, Ha Noi, 2019.

33. Vietnam Business Forum (VBF). The Energy Plan for Manufacturing in Vietnam (Version 2.0). Research on Vietnam's capacity to concentrate MSW resources to encourage investment in clean, safe and affordable energy production, 2019.

34. Surroop, D.; Mohee, R. Power generation from landfill gas, in 2011. Proceeding of $2^{\text {nd }}$ International Conference on Environmental Engineering and Applications, 2011, 17, 237-241.

35. Purmessur, B.; Surroop, D. Power generation using landfill gas generated from new cell at the existing landfill site. J. Environ. Chem. Eng. 2019, 7, 103060.

36. Yaman, C.; Anil, I.; Alagha, O. Potential for greenhouse gas reduction and energy recovery from MSW through different waste management technologies. J. Clean. Prod. 2020, 264, 121432.

37. Williams, P.T. Waste Treatment and Disposal-Second Edition. 2005.

38. Rafiq, A.; Rasheed, A.; Arslan, C.; Tallat, U.; Siddique, M. Estimation of greenhouse gas emissions from Muhammad wala open dumping site of Faisalabad, Pakistan. Geol. Ecol. Landscapes 2018, 2, 45-50.

39. Fallahizadeh, S.; Rahmatinia, M.; Mohammadi, Z.; Vaezzadeh, M.; Tajamiri, A.; Soleimani, H. Estimation of methane gas by LandGEM model from Yasuj municipal solid waste landfill, Iran. MethodsX 2019, 6, 391-398.

40. Tchobanoglous, G.; Theisen, H.; Vigil, S.A. Integrated solid waste management: engineering principles and management issues. New York, USA: McGraw-Hill series in water resources and environmental engineering, 1993.

41. Brander, M. Greenhouse Gases, $\mathrm{CO}_{2}, \mathrm{CO}_{2}-\mathrm{eq}$, and Carbon: What Do All These Terms Mean?. Ecometrica, 2012, pp. 3.

42. Climate Leadership Group - C40 Cities, Workshop on developing city-level greenhouse gas inventory activities - Technical manual for participating experts, Ho Chi Minh city, 2018.

43. Green House Protocol. Global Warming Potential Values, 2015.

44. IPCC. $\mathrm{CH}_{4}$ Emissions from Solid Waste Disposal. IPCC Good Pract. Guid. Uncertain. Manag. Nat. Greenh. Gas Invent. 2006, 419-439.

45. Central Population and Housing Census Steering Committee. The 2019 Vietnam population and housing census, Ha Noi Capital, 2019.

46. General Statistics Office. Vietnam Population Forecast 2014-2049, Ha Noi Capital, 2016. 
47. Talaiekhozani, A.; Nematzadeh, S.; Eskandari, Z.; Dehkordi, A.A.; Rezania, S. Gaseous emissions of landfill and modeling of their dispersion in the atmosphere of Shahrekord, Iran. Urban Clim. 2018, 24, 852-862.

48. Pipatti, R. et al. Chapter 3: Solid Waste Disposal, in 2006 IPCC Guidelines for National Greenhouse Gas Inventories, IPCC, 2006, pp. 1-40.

49. Alexander, A.; Burklin, C.; Singleton, A. Landfill Gas Emissions Model (LandGEM) Version 3.02 User's Guide, 2005, pp. 56.

50. Amrehn, T.S.J. The electricity from garbage, Ha Noi Capital, 2014.

51. ESSOM Co. LTD. Heating Values of Hydrogen and Fuels, 2019. 